\title{
Endothelial Dysfunction, Inflammation and Coronary Artery Disease: Potential Biomarkers and Promising Therapeutical Approaches
}

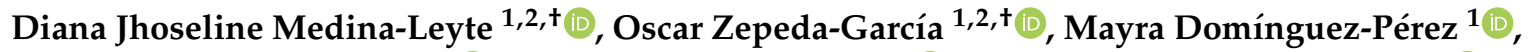 \\ Antonia González-Garrido ${ }^{1}{ }^{(}$, Teresa Villarreal-Molina ${ }^{1}\left(\mathbb{D}\right.$ and Leonor Jacobo-Albavera ${ }^{1, *(1)}$ \\ 1 Genomics of Cardiovascular Diseases Laboratory, National Institute of Genomic Medicine (INMEGEN), \\ Mexico City 14610, Mexico; dianajhos18@gmail.com (D.J.M.-L.); oscar.zega@gmail.com (O.Z.-G.); \\ mdominguez@inmegen.gob.mx (M.D.-P.); gonzalezg.antonia@gmail.com (A.G.-G.); \\ mvillareal@inmegen.gob.mx (T.V.-M.) \\ 2 Posgrado en Ciencias Biológicas, Universidad Nacional Autónoma de México (UNAM), Coyoacán, \\ Mexico City 04510, Mexico \\ * Correspondence: ljacobo@inmegen.gob.mx; Tel.: +55-5350-1900 \\ + These authors contributed equally to this work.
}

Citation: Medina-Leyte, D.J.; ZepedaGarcía, O.; Domínguez-Pérez, M.; González-Garrido, A.; Villarreal-Molina,

T.; Jacobo-Albavera, L. Endothelial Dysfunction, Inflammation and Coronary Artery Disease: Potential Biomarkers and Promising Therapeutical Approaches. Int. J. Mol. Sci. 2021, 22, 3850

https://doi.org/10.3390/ijms22083850

Academic Editor:

Maria Assunta Potenza

Received: 2 March 2021

Accepted: 25 March 2021

Published: 8 April 2021

Publisher's Note: MDPI stays neutral with regard to jurisdictional claims in published maps and institutional affiliations.

Copyright: (C) 2021 by the authors. Licensee MDPI, Basel, Switzerland This article is an open access article distributed under the terms and conditions of the Creative Commons Attribution (CC BY) license (https:// creativecommons.org/licenses/by/ $4.0 /)$
Abstract: Coronary artery disease (CAD) and its complications are the leading cause of death worldwide. Inflammatory activation and dysfunction of the endothelium are key events in the development and pathophysiology of atherosclerosis and are associated with an elevated risk of cardiovascular events. There is great interest to further understand the pathophysiologic mechanisms underlying endothelial dysfunction and atherosclerosis progression, and to identify novel biomarkers and therapeutic strategies to prevent endothelial dysfunction, atherosclerosis and to reduce the risk of developing CAD and its complications. The use of liquid biopsies and new molecular biology techniques have allowed the identification of a growing list of molecular and cellular markers of endothelial dysfunction, which have provided insight on the molecular basis of atherosclerosis and are potential biomarkers and therapeutic targets for the prevention and or treatment of atherosclerosis and CAD. This review describes recent information on normal vascular endothelium function, as well as traditional and novel potential biomarkers of endothelial dysfunction and inflammation, and pharmacological and non-pharmacological therapeutic strategies aimed to protect the endothelium or reverse endothelial damage, as a preventive treatment for $\mathrm{CAD}$ and related complications.

Keywords: coronary artery disease (CAD); atherosclerosis; endothelial cells (EC); endothelium; inflammation; endothelial dysfunction; novel biomarkers; therapeutics

\section{Introduction}

Cardiovascular disease is the leading cause of death worldwide [1]. Coronary artery disease (CAD) is the most common and is characterized by the accumulation of lipids and immune cells in the subendothelial space of the coronary arteries or atherosclerosis. This process involves the inflammatory response of the vascular endothelium [2-4]. Endothelial cells (EC) form a semipermeable monolayer that separates the wall of the arteries from the components of intravascular flow [3-5]. This barrier regulates vascular tone, prevents platelet aggregation, and maintains fluid homeostasis. The endothelium produces vasodilator and vasoconstrictor molecules such as nitric oxide (NO) and endothelin, respectively; the imbalance in production of these vasoactive substances results in the loss of its function, which is defined as endothelial dysfunction $[3,4,6,7]$. Endothelial dysfunction plays an essential role in the development of atherosclerosis and can be triggered and exacerbated by different cardiovascular and cardiometabolic risk factors [8,9]. Currently, there is a wealth of data on endothelial dysfunction and the risk of developing atherosclerosis and $\mathrm{CAD}$. The aim of this review is to describe the most important and up-to-date information 
on the endothelial function, potential biomarkers of endothelial dysfunction and new pharmacological and non-pharmacological promising therapeutic approaches to prevent it.

\section{The Endothelium}

The endothelium is formed by a single layer of EC located in the intima layer of the arteries (Figure 1) [10,11]. A human adult has approximately 10 billion EC which constitute about $1.5 \%$ of total body mass [12]. For many years, the endothelium was considered a simple barrier delimiting the vessel wall $[10,13]$, but is currently known to play an important role in cardiovascular physiology and pathophysiology by regulating vascular tone, coagulation, the exchange of fluids and solutes, inflammation, and angiogenesis, among others [14-26].

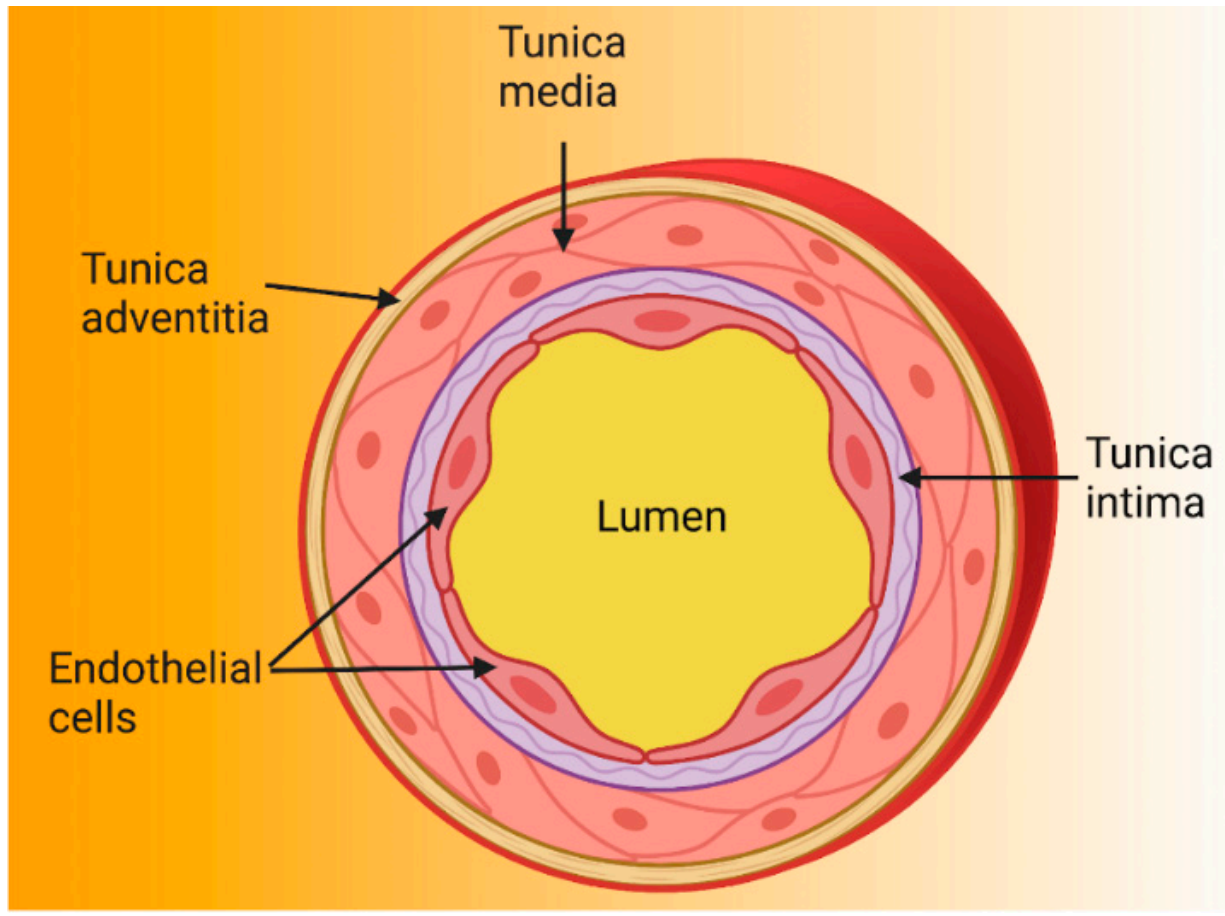

Figure 1. Structure of the arterial wall. Because arteries are supplying blood to tissues and are exposed to high pressure, their walls are thicker than those of other blood vessels. Arterial walls are composed of three layers: the tunica intima is the innermost layer and is made up of endothelial cells anchored to the basal lamina (connective tissue); the tunica media contains vascular smooth muscle cells and regulates vascular tone; and the tunica adventitia is the outermost and contains nerve endings, perivascular adipose tissue, and connective tissue [27-29].

\subsection{Function as a Selective Barrier}

The endothelium is a semi-permeable barrier that allows the passage of water and molecules smaller than $6 \mathrm{~nm}$ to the subendothelial space [11,30,31]. The barrier function is maintained by the glycocalyx and by protein binding complexes (Figure 2). The glycocalyx covers the luminal surface of the endothelium and contributes to vascular permeability regulation and forms a barrier against pathogens [32,33]. It is formed by negatively charged glycoproteins, proteoglycans, and glycosaminoglycans [32,34-36]. These negative charges repel cells such as platelets, erythrocytes, and leukocytes. On the other hand, protein binding complexes (tight junctions, adherens junctions and gap junctions) contribute to the barrier function by maintaining the continuity of the endothelium [25,31,37-39]. 


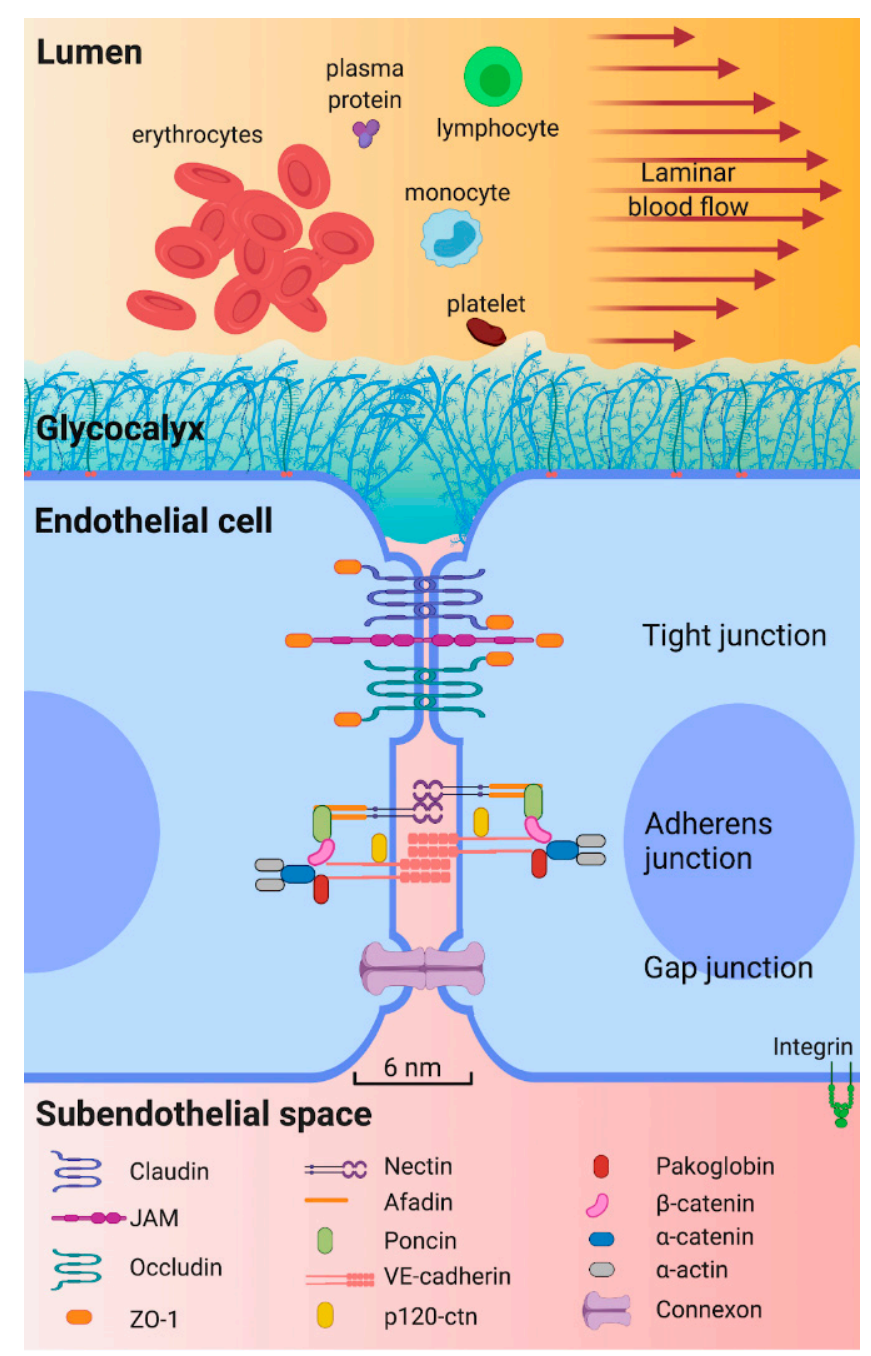

Figure 2. Key structures for epithelium permeability. The arterial endothelium is a semipermeable barrier that prevents passage of blood cells and large molecules from circulating blood to subendothelial space. The glycocalyx and junction complexes are the main structures that help to maintain this function. The glycocalyx, covering the luminal surface of endothelium, comprises proteoglycans, glycosaminoglycans and glycoproteins. Proteoglycans are syndecanes 1, 2 and 4, glypican and perlecan; the main glycosaminoglycans are heparan sulfate, chondritin sulfate, and hyaluronic acid; glycoproteins, involve three families of adhesion molecules, selectin family, the integrin family, and the immunoglobulin superfamily, and their expression depends on the surrounding microenvironment. There are three subtypes of junction complexes connecting adjacent EC. Tight junctions are formed by claudins, junction adhesion molecules (JAM), and occludins. Tight junctions bind to zonule occludens-1 (ZO-1), allowing interaction with cytoskeleton components. Second, adherens junctions are formed by nectin, poncin, afadin, and vascular endothelial cadherin (VE-cadherin) complexes. VE-cadherin binds to filamentous actin (F-actin) via intracellular proteins such as pacoglobin, $\beta$-catenin, $\alpha$-catenin, and $\alpha$-actin. Third, gap junctions consist of two connexons that form an intercellular channel that physically communicates adjacent endothelial cells (EC) and allows passive diffusion of ions and small molecules $[30,40]$.

The transport of lipoproteins through the barrier and into the subendothelial space plays a pivotal role in the pathogenesis of atherosclerosis. Elevated circulating low-density lipoprotein (LDL) levels represent one of the best-characterized risk factors for CAD and the accumulation of LDL under the arterial endothelium represents the first step in the pathogenesis of atherosclerosis [41-44]. Animal models have shown that this transport occurs by transcytosis mediated in part by the SR-BI receptor, and transcytosis was found to be 
saturable and dynamin-dependent in human coronary cells [45]. Notably, apolipoprotein A1 (ApoA1) can also be transported to the subendothelial space by transcytosis, modulated by ATP-binding cassette transporter A1 (ABCA1) [46,47]. ApoA1 is the main protein component of high-density lipoproteins, and although its atheroprotective effect is attributed to its role in reverse cholesterol transport, other atheroprotective mechanisms of ABCA1 expression in EC have been described [48-50].

\subsection{Regulation of Haemostasis and Thrombosis}

Under physiological conditions, EC prevents thrombosis through different anticoagulant and antiplatelet mechanisms. One essential way in which endothelial cells regulate the clotting mechanism is by controlling the expression of binding sites for anticoagulant and procoagulant factors on the cell surface [51]. EC prevent thrombosis by providing tissue factor and thrombin inhibitors and receptors for protein C activation [52].

Over the last decade, additional genes, signaling pathways and molecules involved in the prevention of prothrombotic states have been identified [53-56]. The mitochondrial thioredoxin system prevents the formation of reactive oxygen species (ROS) in EC. The loss of thioredoxin reductase 2 ( Txnrd2) in murine EC generated a prothrombotic endothelium and Txnrd 2 knockout mice developed microthrombi in arteries, arterioles and capillaries, suggesting that the prothrombotic phenotype is systemic [53]. In another study, endothelial-specific deletion of ATG7 (autophagy related 7) in mice attenuated thrombosis and decreased tissue factor expression. Endothelial autophagy is a novel target for reducing arterial and venous thrombosis [55]. The Sirt1/FoxO1 pathway plays an important role in regulating endothelial cell autophagy. Using a human umbilical vein endothelial cell (HUVEC) model, Wu et al. identified that inhibition of the Sirt1/FoxO1 signaling pathway, increased the release of the pro-thrombotic von Willebrand factor, suggesting that Sirt1/FoxO1 are possible therapeutic targets for prevention of thrombosis [56]. In addition, miR-181b and Card10 (caspase recruitment domain family member 10) were found to be important regulators of thrombin-induced EC activation and arterial thrombosis, as $\mathrm{miR}-181 \mathrm{~b}$ overexpression inhibited thrombin-induced activation of NF-kB signaling by targeting the Card10 [54].

The ongoing identification of novel genes and pathways involved in vascular endothelial function is promising for the development of new pharmacologic approaches designed to modulate endothelial activity for the treatment of cardiovascular and thrombotic disorders.

\subsection{Regulation of Vascular Tone}

In resistance arteries, the endothelium plays a fundamental role in the regulation of vascular tone, local blood flow and systemic blood pressure via the generation of various vasoactive stimuli [57]. This monolayer operates to sense, integrate and transduce signals present in the blood and local tissue environment, which then initiate dynamic modulation of contractile activity of the surrounding vascular smooth muscle. In response to mechanical (e.g., shear stress due to blood flow) and chemical (e.g., acetylcholine, bradykinin, ATP) stimuli, EC release vasodilatory factors that regulate the vascular tone [58]. The main vasoconstrictors produced by the endothelium are thromboxane A2 (TXA2) and endothelin-1 (ET-1), while the main endothelial vasodilator factors are NO, prostacyclin (PGI2), and endothelium-derived hyperpolarization factor (EDHF) [28].

Vasodilation and vasoconstriction are regulated by changes in endothelial cytoplasmic $\mathrm{Ca}^{2+}$ concentrations, which are in turn modulated by several signaling pathways and mechanisms. The activation of endothelial TRPV4 (transient receptor potential cation channel, member 4) channels induces vasodilation through $\mathrm{Ca}^{2+}$ influx and activation of inositol 1, 4, 5-triphosphate receptors that release $\mathrm{Ca}^{2+}$ from the endoplasmic reticulum [59]. Moreover, shear stress is an important stimulus for release of endothelium vasoactive factors such as NO, by activating the PIEZO1 (Piezo-type mechanosensitive ion channel component 1) channel, which results in the release of adrenomedullin and the downstream 
production of $\mathrm{NO}$ [60]. The disequilibrium in the production of these substances triggers endothelial dysfunction.

By regulating vascular tone, the endothelium plays an essential role in long-term cardiac performance and adequate endothelial function prevents cardiovascular events. Continued development and refinement of therapeutic strategies to prevent endothelial dysfunction or damage should thus have direct health-related benefits.

\subsection{Endothelial Dysfunction}

Endothelial dysfunction is generated when there is an imbalance in the production or bioavailability of endothelium-derived NO, generating a decreased vasodilator response and a prothrombotic and proinflammatory endothelium. During the inflammatory process induced by different risk factors as hypertension, oxidized LDL (oxLDL) and diabetes, there is an increase in the production of interleukin-1 (IL-1), interleukin-6 (IL-6), TNF- $\alpha$ and $\mathrm{C}$-reactive protein (CRP) that generate the endothelial proinflammatory phenotype characterized by an increase in E-selectin, vascular cell adhesion molecule-1 (VCAM-1) and intercellular adhesion molecule 1 (ICAM-1) expression (Figure 3) [61,62]. Therefore, there is a greater interest in the search for new biomarkers and therapeutic strategies that help to prevent endothelial dysfunction and reduce the risk of developing CAD and its complications.

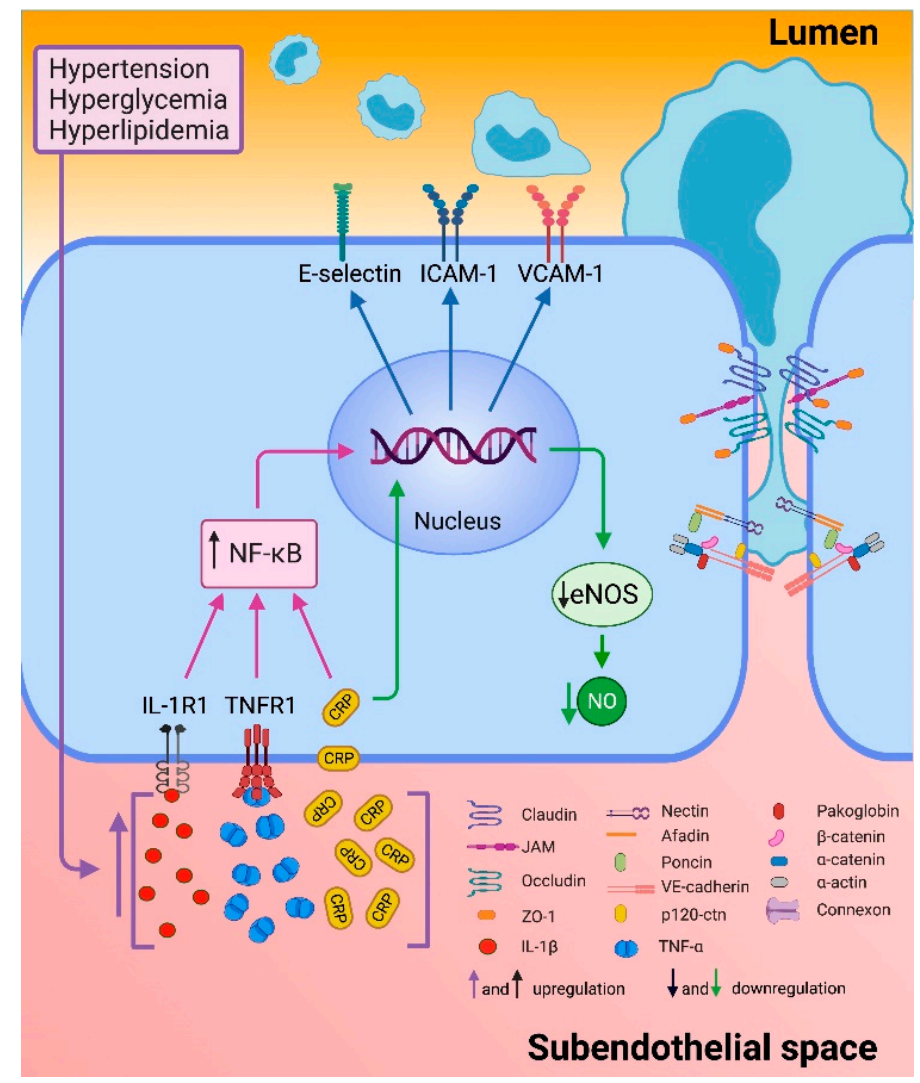

Figure 3. Endothelial inflammation. Endothelial dysfunction is triggered by different cardiovascular risk factors such as hypertension, hyperglycemia, and hyperlipidemia. These events increased production of interleukin 1 beta (IL-1 $\beta$ ), tumor necrosis factor alpha (TNF- $\alpha$ ), and C reactive protein (CRP). Proinflammatory cytokines bind to their receptors and culminate in the activation of the nuclear transcription factor $\mathrm{\kappa B}(\mathrm{NF}-\mathrm{kB})$ that stimulate the transcription of selectin-E, intercellular adhesion molecule-1 (ICAM-1) and vascular cell adhesion molecule-1 (VCAM-1). CRP down-regulates endothelial nitric oxide synthase (eNOS) transcription and destabilizes eNOS mRNA, resulting in decreased nitric oxide (NO). Furthermore, the reorganization of actin filaments allows the opening of intercellular junctions through other signaling pathways $[63,64]$. 
The role of ROS and increased oxidative stress is essential in endothelial dysfunction. ROS are reactive intermediates of molecular oxygen that act as important second messengers within cells; however, an imbalance between generation of reactive ROS and antioxidant defense systems represents the primary cause of endothelial dysfunction, leading to vascular damage in both metabolic and atherosclerotic diseases. In endothelial cells, $\mathrm{NO}$ is essential for vascular homeostasis. Reduction in NO bioavailability, resulting from reduced NO production and/or increased NO degradation by superoxide anion, marks the onset of endothelial dysfunction [65]. Identification of new endothelial dysfunction-related oxidative stress markers represents a research goal for better prevention and therapy of CVD. New-generation therapeutic approaches based on carriers, gene therapy, cardiolipin stabilizer, and enzyme inhibitors have proved useful in clinical practice to counteract endothelial dysfunction. Experimental studies are in continuous development to discover new personalized treatments [66]. Both endothelial dysfunction-related oxidative stress markers and therapeutic approaches have been thoroughly described elsewhere in extensive reviews [4,65-74].

\section{Biomarkers}

Research on biomarkers and their clinical application has grown exponentially over the last decades [75]. Systemic biomarkers have provided invaluable insight into the pathophysiology of atherosclerosis and the development of novel therapies [76]. Endothelial dysfunction and inflammation play a central role in the development and progression in CAD $[77,78]$. Mediators of inflammation are secreted by inflammatory and vascular cells in the atherosclerotic plaque, or by organs such as the liver or adipose tissue [79]. Thus, several inflammation-related factors are considered biomarkers for early prediction of CAD.

\subsection{Traditional Biomarkers}

Acute-phase proteins, cytokines, adhesion molecules and microparticles have been extensively studied as endothelial dysfunction and inflammation markers in clinical studies.

\subsubsection{Acute-Phase Proteins}

C-Reactive Protein (CRP). CRP is a systemic inflammatory mediator and a major acute phase reactant produced mainly by hepatocytes after stimulation by cytokines such as IL-1, IL-6 and TNF- $\alpha$ [64]. CRP down-regulates synthase endothelial nitric oxide (eNOS) transcription in EC, resulting in decreased NO release [80]. Moreover, CRP was found to increase ICAM-1, VCAM-1, and E-selectin expression in HUVEC [81]. Consistently, several clinical trials have reported that CRP levels are associated with endothelial dysfunction and different stages of CAD [64,82]. Higher hsCRP plasma levels were associated with coronary endothelial dysfunction, suggesting it is an independent marker of abnormal coronary vasoreactivity in patients with non-obstructive coronary disease [83]. Recently, high hs-CRP levels were found to correlate positively with IL-6 and LDL-cholesterol and increased CAD risk and mortality [84].

Fibrinogen. The canonical role of the hemostatic and fibrinolytic systems is to maintain vascular integrity. Perturbations in either system can prompt primary pathological end points of hemorrhage or thrombosis with vessel occlusion. However, fibrinogen and proteases controlling its deposition and clearance, including prothrombin and plasminogen, have powerful roles in driving acute and reparative inflammatory pathways that affect the spectrum of tissue injury, remodeling, and repair. Although thrombin can clearly influence inflammatory events through protease-activated receptors signaling pathways, fibrinogen as a downstream target of thrombin is one of the most potent contributors among all coagulation system proteins to the inflammatory response [85]. Fibrinogen is a circulating glycoprotein that plays a role in wound healing, thrombosis, platelet aggregation, and inflammation, as well as cell adhesion, vasoconstriction, and chemotactic activity [86]. Increased plasma fibrinogen levels are associated with an increased risk of CAD [87] 
and myocardial infarction [88]. The correlation between fibrinogen levels and CAD risk has been consistently documented by several prospective studies that include hundreds of cases and controls $[89,90]$. In addition, recent studies have reported that fibrinogen plasma concentrations show a positive correlation with the degree and composition of the coronary plaque $[91,92]$ but not with atherosclerotic plaque vulnerability as diagnosed by optical coherence tomography [93]. Moreover, elevated fibrinogen levels were associated with CAD severity and mortality [92,94,95], and are a well-established independent risk factor for CAD. Interestingly, epidemiological studies have specifically associated increased circulating levels of the fibrinogen $\gamma \mathrm{A} / \gamma^{\prime}$ isoform with arterial and venous thrombosis risk and with increased incidence of coronary artery disease [96], myocardial infarction [97] and ischemic stroke [98], suggesting that $\gamma \mathrm{A} / \gamma^{\prime}$ fibrinogen promotes arterial thrombosis. Nevertheless, a prospective study found that alternatively spliced $\gamma^{\prime}$ fibrinogen does not influence CVD events through its prothrombotic properties, and that $\gamma^{\prime}$ fibrinogen concentrations seem to reflect general inflammation that accompanies and may contribute to atherosclerotic CVD [99]. Future studies are required to continue exploring the value of fibrinogen as a biomarker for inflammation and/or thrombosis and cardiovascular disease.

Serum Amyloid A (SSA). Serum amyloid A (SAA) refers to a family of proteins encoded by several genes. Humans have 4 SAA genes (SAA1, SAA2, SAA3, and SAA4), and only SAA1 and SAA2 encode acute phase proteins that are highly inducible during the acutephase response. These proteins have pro-inflammatory and pro-atherogenic properties and are well known for being involved in atherosclerosis development [100]. Several clinical studies have evaluated the role of SAA levels in CAD severity and future cardiovascular events [101-103]. In the Women's Ischemia Syndrome Evaluation study, elevated circulating SAA levels were associated with angiographic severity of CAD and were highly predictive of a 3-year risk for cardiovascular events [102]. The Thrombogenic Factors and Recurrent Coronary Events (THROMBO) study reported that SAA levels measured two months after myocardial infarction, were associated with infarction severity, with only a trend for increasing the risk of recurrent coronary events over two years [101]. Moreover, a prospective cohort study reported that serum levels of the SAA/LDL complex were associated with an increased risk of a future cardiac event in patients with stable CAD, suggesting SAA/LDL complex could be a more sensitive marker than CRP or SAA for the prediction of prognosis in CAD patients [103]. More recently, elevated SAA1 levels were associated with the presence of acute coronary syndrome (ACS) and with the severity of CAD in ACS patients [104], and high SAA plasma levels were found to be associated with unstable CAD in the prospective Ludwigshafen Risk and Cardiovascular Health (LURIC) study [105]. Altogether, these studies underline the importance of inflammation in CAD and the prognostic relevance of inflammatory biomarkers in CAD severity and recurrent cardiovascular events.

\subsubsection{Cytokines}

Cytokines include many pleiotropic proteins that have been extensively implicated in the process of inflammation and atherosclerosis. Pro-inflammatory cytokines such as TNF- $\alpha$, IL-6, IL-8, and IL-18 are essential inflammatory mediators, aggravating the inflammatory response and inducing the expression of adhesion molecules in endothelial cells and leukocytes (E-selectin, and P-selectin), which worsen endothelial dysfunction.

Tumor Necrosis Factor alpha (TNF- $\alpha$ ). TNF- $\alpha$ plays an important role in endothelial dysfunction and inflammation [106]. TNF- $\alpha$ activates endothelial cells to express and release various inflammatory cytokines, chemokines and adhesion molecules necessary for the recruitment and migration of monocytes to the vessel intima [107]. In clinical studies, increased TNF- $\alpha$ circulating levels were found to be associated with the endothelial dysfunction in hypertensive patients [108]; with carotid atherosclerosis thickness in patients with early atherosclerosis [109] and with CAD risk [110,111]. Moreover, increased plasma TNF- $\alpha$ levels were found to activate monocytes and to directly trigger foam cell formation [112]. 
Interleukin 6 (IL-6). Interleukin-6 is an important cytokine involved in many different immunological processes such as the major regulator of acute phase response proteins and plays a crucial role in CAD $[113,114]$. Although there are few studies of IL-6 as a biomarker in CAD, it seems to have a potential role as a biomarker in coronary plaque instability and has been associated with clinical outcomes in CAD patients. In individuals with ischemic heart disease, IL-6 plasma levels were associated with the presence of thin-cap fibroatheroma observed with optical coherence tomography, and IL-6 levels showed higher sensitivity and specificity than hs-CRP for the prediction of plaque instability [115]. In addition, in a sub-analysis of the STABILITY (stabilization of atherosclerotic plaque by initiation of darapladib therapy) trial, plasma IL-6 levels in patients with stable CAD were associated with several health outcomes, including cardiovascular and all-cause mortality, myocardial infarction and heart failure [116]. Future studies are required to further explore and validate the value of IL-6 levels as a biomarker for endothelial dysfunction and cardiovascular disease.

Interleukin 8 (IL-8). IL-8 is a potent chemoattractant for neutrophils and T lymphocytes. Several studies showed that elevated IL-8 levels may be useful as a biomarker for CAD [117-119]. Interestingly, a prospective study including angiographically confirmed stable CAD patients reported that among ten cytokines (IL- $1 \beta$, IL-2, IL-4, IL-5, IL-6, IL-8, IL-10, TNF- $\alpha$, granulocyte-macrophage colony stimulating factor and IFN-gamma) and hs-CRP, only elevated IL-8 serum levels were considered as a potential marker of longterm outcome [120]. This suggests that IL-8 may be a predictor of cardiovascular events independent of other cytokines and hs-CRP in patients with CAD.

Interleukin 18 (IL-18). IL-18 is a pro-inflammatory cytokine that belongs to the IL-1 superfamily. It is produced mainly by macrophages and has pleiotropic functions inducing the expression of other cytokines implicated in atherosclerosis [121]. In 2001, Mallat et al. for the first time reported significant IL-18 expression in human carotid atherosclerotic plaques and found an association between IL-18 mRNA transcript levels and clinical and pathological signs of plaque instability [122]. Moreover, plasma or serum IL-18 concentrations have been significantly associated with coronary plaque area in postinfarction patients [123], with fatal cardiovascular events over a 4 year follow up in patients with stable and unstable angina [124] and with CAD in a case-control study performed in the Chinese population [125]. Consistently, serum IL-18 levels were found to be a predictor of coronary events in healthy European men [126] and two independent meta-analyses identified an association between IL-18 and CAD, suggesting circulating IL-18 levels as a prospective and independent marker of CAD risk [110,127].

Other circulating cytokines have been recently proposed as promising CAD markers such as IL-37 levels, which were increased in patients with acute coronary syndrome and associated with a worse clinical outcome after ST-segment elevation acute myocardial infarction [128]. Although a wide range of data that support the potential roles of cytokines as CAD biomarkers, further data from clinical and epidemiologic studies are needed to assess the role and predictive values of cytokines or cytokine combinations in CAD.

\subsubsection{Cell Adhesion Molecules (CAM)}

In EC, inflammatory cytokines induce increased expression of CAM such as E-selectin, P-selectin, ICAM-1, and VCAM-1. These are transmembrane proteins that promote endothelial dysfunction and leukocyte migration $[129,130]$. Activated EC produce soluble types of these adhesion molecules that are secreted into the bloodstream. Many studies have reported increased circulating levels of soluble E-selectin, VCAM-1 and/or ICAM-1 associated with CAD, CAD severity and complications [129,131-140]. However, because most of these CAM are produced not only by the endothelium but also by leukocytes and platelets, these molecules are not specific biomarkers accurately reflecting endothelial damage [141,142]. Therefore, although circulating CAM reflect early inflammation and EC activation, they have a limited diagnostic value when measured alone [130]. 


\subsubsection{Cellular Markers}

Microparticles (MP) are small vesicles $(0.1$ to $1 \mu \mathrm{m})$ shed from the plasmatic membrane of different cells, such as erythrocytes, leukocytes, platelets, and EC [130]. Increased circulating endothelial MP (EMP) concentrations have been associated with endothelial dysfunction in patients with CAD [143] and with ACS [144]. Moreover, patients with myocardial infarction registered $79 \%$ higher production of EMPs compared to patients with stable CAD [145]. Interestingly, EMP concentrations in patients with ACS and stable CAD patients were higher in the coronary than in the peripheral circulation [146]. This is relevant because experimental evidence using EMPs derived from dysfunctional endothelial cells suggests that EMPs might be involved in the regulation of monocyte/macrophage function producing pro-inflammatory cytokines [144].

Monocytes have also been identified as potential markers of vascular dysfunction and CAD [147-149]. In patients with CAD, higher monocyte counts were associated with increased risk of cardiovascular events and with peripheral endothelial dysfunction measured by peripheral arterial tonometry [147]. Regarding specific monocyte subsets, in a group of CAD patients undergoing coronary artery bypass grafting, endothelial dysfunction was associated with higher expression of activation marker CD11c selectively on CD14+CD16++ monocytes, which were associated with more advanced vascular dysfunction measured as NO-bioavailability and vascular ROS production [148]. Moreover, in patients undergoing cardiac catheterization, CAD severity was directly associated with CD16+ monocytes and inversely associated with M2 macrophages, suggesting that measures of monocyte and macrophage subtypes could also be potential biomarkers in CAD [149].

\subsubsection{Others}

Asymmetric dimethylarginine (ADMA) and Symmetric dimethylarginine (SDMA). ADMA is an endogenous inhibitor of NOS via competition with L-arginine, which is a NOS substrate and a structural analogue of ADMA [150]. Diminished nitric oxide synthesis due to eNOS downregulation appears to play a prominent role in vasoactive factor imbalance, impairment of endothelial hemostasis and the early development of atherosclerosis [151]. ADMA is one of the most potent endogenous inhibitors of the three isoforms of NOS and is involved in the pathogenesis of an array of diseases including systemic sclerosis and rheumatoid arthritis, where derangement of nitric oxide/ADMA pathway has been observed [152,153]. ADMA has been recognized as a hallmark of endothelial dysfunction and related to many cardiovascular risk factors such as hypertension [154], obesity [155], hypertriglyceridemia [156] and type 1 and type 2 diabetes mellitus (T2DM) [157,158]. Furthermore, longitudinal studies have revealed that ADMA predicts cardiovascular morbidity and mortality in both myocardial infarction [159] and stroke patients [160]. Elevated plasma ADMA concentrations not only correlate with the presence of plaques, particularly in the carotid artery, but also predict the risk of future lesion development, myocardial infarction and stroke [161]. Moreover, serum ADMA levels significantly correlated with the presence and extent of coronary atherosclerosis in patients undergoing elective coronary angiogram. Patients with reduced endothelial function in at least one vessel as measured by fractional flow reserve had significantly higher ADMA levels than patients without functionally significant $\mathrm{CAD}$, concluding that serum ADMA levels are independent predictors of coronary atherosclerosis extent and functional significance [162].

Even though SDMA is not a direct inhibitor of NOS, it can alter L-arginine concentrations via competition with amino acid transporters [161]. SDMA was initially thought to be biologically inert and was therefore included in early epidemiological studies as a negative control [163]. Afterwards, SDMA was found to be a sensitive parameter of renal function, sometimes even more sensitive than creatinine [164]. Interestingly, Schulze et al. showed that SDMA predicts all-cause mortality following ischemic stroke even after adjustment for renal function and novel risk factors such as C-reactive protein, albumin, beta-thromboglobulin, and the von Willebrand factor [165]. It has also been proposed that SDMA accumulates in high-density lipoprotein (HDL) fractions from patients with chronic 
kidney disease activating the toll like receptor 2 (TLR-2) and enhancing an endothelial proinflammatory response [166]. Finally, in a prospective observational study, homoarginine (a homologue of L-arginine)/ADMA ratio and homoarginine/SDMA ratio were inversely associated with cardiovascular death and independent predictors of cardiovascular mortality in claudicant patients with lower extremity arterial disease. Further investigations are needed to explore whether the homoarginine/SDMA ratio is an appropriate predictor for cardiovascular death in patients with other cardiovascular diseases [167].

\subsection{Novel Potential Biomarkers}

Systemic biomarkers are invaluable for basic and clinical research. Numerous studies have assessed the role of cells, proteins, lipids and other metabolites in the pathophysiology of endothelial dysfunction and atherosclerosis, as well as their potential usefulness in the clinical setting. Recently, liquid biopsies and new molecular biology techniques have identified many novel potential biomarkers of inflammation and endothelial dysfunction biomarkers associated with CAD, described in Table 1 [140,160,161].

Table 1. Recently identified potential biomarkers of inflammation and endothelial dysfunction in coronary artery disease (CAD).

\begin{tabular}{|c|c|c|c|}
\hline Biomarker & Model & Implication or Considerations & Study \\
\hline Adiponectin & Cohort of T1DM patients & $\begin{array}{l}\uparrow \text { Adiponectin serum levels in T1DM } \\
\text { patients are proposed as an early marker } \\
\text { of subclinical atherosclerosis. }\end{array}$ & [168] \\
\hline ANGPTL8 & Cohort of CAD patients & $\begin{array}{l}\text { CAD patients had significantly higher } \\
\text { serum ANGPTL8 levels and ANGPTL8 } \\
\text { was independently associated with TG } \\
\text { and ICAM-1 in CAD patients. }\end{array}$ & [169] \\
\hline CTRP9 & Cohort of patients with CAD and T2DM & $\begin{array}{l}\uparrow \text { expression of CTRP9 in patients with } \\
\text { CAD and T2DM. }\end{array}$ & [170] \\
\hline Cyr61 & Cohort of CAD patients & $\begin{array}{l}\text { Serum Cyr61 levels were higher in CAD } \\
\text { patients than in controls and correlated } \\
\text { positively with Gensini score and } \\
\text { CRP levels. }\end{array}$ & [171] \\
\hline Endocan & $\begin{array}{l}\text { Cohort of patients with isolated CAE } \\
\text { Cohort of patients with CSX }\end{array}$ & $\begin{array}{l}\text { Plasma endocan levels were increased in } \\
\text { patients with isolated CAE as compared } \\
\text { to controls. } \\
\text { Endocan serum levels were higher in CSX } \\
\text { patients than in controls and are } \\
\text { proposed as an acute marker of } \\
\text { microvascular disease. }\end{array}$ & $\begin{array}{l}{[172]} \\
{[173]}\end{array}$ \\
\hline Galectin-3 & Cohort of CAD patients & $\begin{array}{l}\text { Serum galectin- } 3 \text { levels were higher in } \\
\text { CAD patients than controls and were } \\
\text { associated with severity of CAD. }\end{array}$ & [174] \\
\hline $\begin{array}{l}\text { Human neutrophil } \\
\text { peptides or } \alpha \text {-defensin }\end{array}$ & $\begin{array}{l}\text { Cohort of CAD patients, } \\
\text { hyperlipidemic patients and controls }\end{array}$ & $\begin{array}{l}\text { Patients with hyperlipidemia and CAD } \\
\text { have showed increased } \alpha \text {-defensin in } \\
\text { blood. } \alpha \text {-defensin is proposed as a } \\
\text { potential inflammation marker that may } \\
\text { predict the risk of CAD. }\end{array}$ & [175] \\
\hline
\end{tabular}


Table 1. Cont.

\begin{tabular}{|c|c|c|c|}
\hline Biomarker & Model & Implication or Considerations & Study \\
\hline \multirow{3}{*}{ Irisin } & Cohort of obese children. & $\begin{array}{l}\text { Obese children showed a decreased level } \\
\text { of Irisin as compared to lean children. } \\
\downarrow \text { Irisin levels correlated inversely with } \\
\text { several markers of inflammation and } \\
\text { endothelial dysfunction in } \\
\text { obese children. }\end{array}$ & \multirow{3}{*}{$\begin{array}{l}{[176]} \\
{[177]} \\
{[178]}\end{array}$} \\
\hline & $\begin{array}{l}\text { Cohort of children and adolescents with T2DM, } \\
\text { MS and controls }\end{array}$ & $\begin{array}{l}\text { T2DM and MS patients showed } \\
\text { decreased levels of Irisin as compared to } \\
\text { healthy controls. Irisin levels showed a } \\
\text { negative correlation with sVCAM-1, } \\
\text { sICAM- } 2 \text { and MCP- } 1 \text { in the total } \\
\text { population of children and adolescents. }\end{array}$ & \\
\hline & $\begin{array}{l}\text { Meta-analysis of } 7 \text { case-control studies } \\
\text { involving } 867 \text { patients of CAD and } 700 \text { controls }\end{array}$ & $\begin{array}{l}\text { Circulating irisin concentrations were } \\
18.10 \mathrm{ng} / \mathrm{mL} \text { lower in patients with CAD } \\
\text { than in healthy controls. }\end{array}$ & \\
\hline Lp-PLA2 & Cohort of patients with CAD + ASC & $\begin{array}{l}\text { Circulating plasma Lp-PLA2 levels were } \\
\text { higher CAD+ACS patients than in } \\
\text { controls and showed a positive } \\
\text { association with CAD risk. }\end{array}$ & [179] \\
\hline NGAL and YKL-40 & Prospective study of T2DM patients. & $\begin{array}{l}\text { NGAL and YKL-40 serum levels are } \\
\text { increased in T2DM subjects with } \\
\text { subclinical CAD and are associated with } \\
\text { the risk of future cardiovascular events. }\end{array}$ & [180] \\
\hline \multirow[b]{2}{*}{ Resistin and Visfatin } & Cohort of CAD patients. & $\begin{array}{l}\text { Resistin and visfatin serum levels were } \\
\text { higher in patients with acute myocardial } \\
\text { infarction than in patients with } \\
\text { stable angina. }\end{array}$ & \multirow[b]{2}{*}{$\begin{array}{l}{[181]} \\
{[182]}\end{array}$} \\
\hline & Cohort of patients with CAE. & $\begin{array}{l}\text { Visfatin serum levels were higher in } \\
\text { patients with both CAE + CAD and are } \\
\text { proposed as an independent marker for } \\
\text { severity of coronary ectasia in both } \\
\text { isolated CAE and CAD coexisting with } \\
\text { CAE groups. }\end{array}$ & \\
\hline Renalase & $\begin{array}{l}\text { Patients presenting to the emergency room } \\
\text { with acute chest pain, with diagnostic workup } \\
\text { including PET to identify CMD. }\end{array}$ & $\begin{array}{l}\uparrow \text { Renalase serum levels were associated } \\
\text { with symptomatic CMD in patients } \\
\text { presenting with acute chest pain, } \\
\text { increased peripheral renalase blood levels } \\
\text { are proposed as a biomarker for CMD. }\end{array}$ & [183] \\
\hline Sortilin & Cohort of CAD patients & $\begin{array}{l}\text { Sortilin serum levels were higher in CAD } \\
\text { patients than in controls and correlated } \\
\text { with inflammatory cytokine levels. }\end{array}$ & [184] \\
\hline suPAR & Cohort of patients with non-obstructive CAD. & $\begin{array}{l}\text { In patients with non-obstructive CAD, } \\
\text { plasma suPAR levels correlated } \\
\text { negatively with coronary flow reserve. } \\
\text { suPAR levels are proposed as an } \\
\text { independent risk predictor of coronary } \\
\text { microvascular function. }\end{array}$ & [185] \\
\hline
\end{tabular}


Table 1. Cont.

\begin{tabular}{|c|c|c|c|}
\hline Biomarker & Model & Implication or Considerations & Study \\
\hline \multirow{2}{*}{ PCSK9 } & $\begin{array}{l}\text { Cohort of HIV+ patients under } \\
\text { retroviral therapy }\end{array}$ & $\begin{array}{l}\text { PCSK9 serum levels were higher in HIV+ } \\
\text { than in age and LDL-C level matched } \\
\text { HIV-patients and were inversely } \\
\text { associated with coronary endothelial } \\
\text { function measured by } \\
\text { magnetic resonance. }\end{array}$ & \multirow{2}{*}{$\begin{array}{l}{[186]} \\
{[187]}\end{array}$} \\
\hline & Cohort of patients with suspected CAD & $\begin{array}{l}\text { Low PCSK9 plasma levels were } \\
\text { associated with unfavorable metabolic } \\
\text { profile and with diffuse non-obstructive } \\
\text { coronary atherosclerosis as determinated } \\
\text { by coronary computed } \\
\text { tomography angiography. }\end{array}$ & \\
\hline $\begin{array}{l}\text { Phosphatidylcholine and } \\
\text { lysophosphatidylcholine }\end{array}$ & Cohort of patients with CAD and PAD & $\begin{array}{l}\text { Serum of phosphatidylcholine and } \\
\text { lysophosphatidylcholine levels were } \\
\text { lower in CAD and PAD patients than } \\
\text { in controls. }\end{array}$ & [188] \\
\hline $\begin{array}{c}\text { lncRNA KCNQ1OT1, } \\
\text { HIF1A-AS2 } \\
\text { and APOA1-AS }\end{array}$ & Cohort of patients with CAD & $\begin{array}{l}\text { KCNQ1OT1, HIF1A-AS2 and APOA1-AS } \\
\text { in patients with CAD. ROC analysis } \\
\text { confirmed their suitability as biomarkers } \\
\text { of CAD. }\end{array}$ & [189] \\
\hline $\begin{array}{c}\text { Circulating } \\
\text { lncRNA IFNGAS1 }\end{array}$ & Cohort of patients with CAD & $\begin{array}{l}\text { Increased lncRNA IFNGAS1 plasma } \\
\text { levels were associated with CAD risk and } \\
\text { severity assessed by } \\
\text { coronary angiography. }\end{array}$ & [190] \\
\hline Circulating microRNA-941 & Cohort of patients with ACS. & $\begin{array}{l}\text { microRNA- } 941 \text { plasma levels were higher } \\
\text { in patients with ACS and ST-elevation } \\
\text { myocardial infarction than in controls. }\end{array}$ & [191] \\
\hline Circulating microRNA-33 & Cohort of patients with CAD. & $\begin{array}{l}\text { microRNA- } 33 \text { expression is higher in } \\
\text { CAD patients than controls. }\end{array}$ & [192] \\
\hline Circulating microRNA-92a & Cohort of patients with T2DM + CAD & $\begin{array}{l}\uparrow \text { Expression of microRNA-92a, was } \\
\text { significantly associated with T risk of } \\
\text { acute coronary T2DM. miR-92a levels } \\
\text { were identified as an independent } \\
\text { predictive factor for ACS events in the } \\
\text { patients with T2DM. }\end{array}$ & [193] \\
\hline $\begin{array}{c}\text { Circulating } \\
\text { microRNAs-331, 151-3p }\end{array}$ & Cohort of patients with STEMI. & $\begin{array}{l}\text { MicroRNAs-331 and } 151-3 p \text { were } \\
\text { significantly up-regulated in patients } \\
\text { with STEMI as compared to patients with } \\
\text { stable angina and controls. These } \\
\text { miRNAs are proposed as suitable } \\
\text { biomarkers than may be associated with } \\
\text { plaque rupture. }\end{array}$ & [194] \\
\hline $\begin{array}{l}\text { Serum exosomal } \\
\text { microRNA-21, } \\
126 \text { and PTEN. }\end{array}$ & Cohort of patients with ACS. & $\begin{array}{l}\text { Serum levels of exosomal microRNAs-21, } \\
126 \text { and PTEN were higher in patients } \\
\text { with ACS than in controls. Exosomal } \\
\text { microRNA- } 126 \text { showed a positive } \\
\text { correlation with coronary artery } \\
\text { stenosis severity. }\end{array}$ & [195] \\
\hline
\end{tabular}


Table 1. Cont.

\begin{tabular}{|c|c|c|c|}
\hline Biomarker & Model & Implication or Considerations & Study \\
\hline \multirow[t]{2}{*}{ Circulating microRNA-145 } & Cohort of patients with ACS. & $\begin{array}{l}\downarrow \text { Expression of microRNA- } 145 \text { in ACS } \\
\text { patients as compared to controls. } \\
\text { microRNA-145 levels correlated with } \\
\text { other endothelial inflammation and } \\
\text { damage markers. }\end{array}$ & \multirow[t]{2}{*}{ [196] } \\
\hline & ACS coronary ligation rat model & $\begin{array}{l}\text { microRNA- } 145 \text { overexpression in an ACS } \\
\text { rat model improved endothelial injury } \\
\text { and abnormal inflammation, suggesting } \\
\text { it may be a therapeutic target. }\end{array}$ & \\
\hline Circulating microRNA-22 & Cohort of patients with CSF. & $\begin{array}{l}\text { microRNA- } 22 \text { expression was increased } \\
\text { in patients with CSF as compared to } \\
\text { those with normal coronary flow. } \\
\text { Increased microRNA- } 22 \text { circulating levels } \\
\text { are proposed as a suitable biomarker } \\
\text { of CSF. }\end{array}$ & [197] \\
\hline
\end{tabular}

Expression levels of miR-1, miR-133, miR-208a, miR-206, miR-17, miR-29, miR-223, miR-326, and 155 in PBMCs were significantly increased in SCF

microRNA signature Cohort of patients with CSF. patients as compared to controls.

Expression levels of microRNAs: miR-15a, miR-21, miR-25, miR-126, $\mathrm{miR}-16$, and miR-18a were significantly decreased in patients with SCF patients as compared to control group.

Abbreviations: $\uparrow$ (increased), $\downarrow$ (decreased), T1DM (type 1 diabetes mellitus), ANGPTL8 (angiopoietin like 8), CAD (coronary artery disease), TG (triglycerides), CTRP9 (C1 q/TNF-related protein 9), T2DM (type 2 diabetes mellitus), Cyr61(cysteine-rich protein 61), CRP (C reactive protein), CAE (coronary artery ectasia), CSX (cardiac syndrome X), MS (metabolic syndrome), sVCAM-1 (soluble vascular cell adhesion molecule-1), sICAM-2 (soluble intercellular adhesion molecule 1), MCP-1 (monocyte chemoattractant protein), Lp-PLA2 (lipoprotein associated phospholipase A2), ACS (acute coronary syndrome), NGAL (neutrophil gelatinase-associated lipocalin), YKL-40 (chitinase-3 like protein 1), CMD (coronary microvascular dysfunction), suPAR (soluble urokinase-type plasminogen activator receptor), PCSK9 (proprotein convertase subtilisin/kexin type 9), HIV (human immunodeficiency virus), LDL-C (low density lipoprotein-cholesterol), PAD (peripheral artery disease), lncRNA (long non-coding RNA), KCNQ1OT1 (KCNQ1 opposite strand/antisense transcript 1), HIF1A-AS2 (HIF1A antisense RNA 2), APOA1-AS (APOA1 antisense RNA), STEMI (ST-segment elevation myocardial infraction), PTEN (phosphatase and tensin homolog), CSF (coronary slow flow).

The growing list of potential biomarkers associated with CAD, ACS, STEMI and other cardiovascular phenotypes are promising, but require validation in future studies.

\subsection{Therapeutic Strategies by Prevent Endothelial Dysfunction}

Maintaining endothelial function is essential to prevent CAD and promote cardiovascular and cardiometabolic health. Some studies suggest that endothelial dysfunction may be prevented and even reversed by drug treatment, alternative therapies and lifestyle changes [199].

\subsubsection{Pharmacological Therapy}

Endothelial dysfunction is a process that precedes atherosclerosis. In this context, it is essential to understand the mechanism of drugs to prevent endothelial dysfunction. Medical treatments can have short and long-term effects, and some have pleiotropic effects. These effects may act directly on EC and reduce cardiovascular risk. There are many risk factors that can accelerate development of CAD such as hypertension, hyperlipidemia and hyperglycemia which are modifiable by medical treatment [61].

Glucose lowering drugs. Several glucose lowering drugs have been tested for prevention of endothelial dysfunction both in vitro and in vivo. In human abdominal aortic endothe- 
lial cells, the effect of empagliflozin, a sodium-glucose co-transporter-2 inhibitor (SGLT2i), preserved glycocalyx integrity, increased heparan sulphate synthesis and restored the mechanotransduction response of ECs with damaged glycocalyx. Moreover, empagliflozin promoted an anti-inflammatory phenotype of these cells under pro-inflammatory conditions [200]. On the other hand, in nondiabetic apolipoprotein E deficient (Apoe-/-) mice, the dipeptidyl peptidase-4 (DPP-4) inhibitor vildagliptin reduced VCAM-1 expression and attenuated atherosclerotic lesion progression in the aortic arch, and improved EC function by the activation of eNOS [201]. Metformin is a biguanide broadly used for the treatment of T2DM. The effect of metformin therapy on endothelial function was evaluated in prediabetic patients with stable angina and nonobstructive coronary stenosis and was found to decrease blood concentrations of inflammation markers such as IL-1, IL-6, TNF- $\alpha$ and CRP in these patients [61]. In a prospective study, metformin treatment reduced the frequency of major adverse cardiac events after 24 months of follow-up in prediabetic patients [202]. Therefore, the use of glucose-lowering drugs in early stages are likely to prevent endothelial dysfunction and progression of atherosclerosis.

Statins. Statin therapy reduces endogenous cholesterol synthesis by inhibiting hydroxymethylglutaryl coenzyme A reductase activity. Simvastatin is a commonly used hypolipidemic drug with effects on EC function. A low simvastatin dose increased HUVEC viability and reduced VCAM- 1 and ICAM- 1 expression, while statin therapy inhibited endothelial reticulum stress by reducing intracellular cholesterol accumulation and blocking intracellular signal transduction in the Wnt/ $\beta$-catenin pathway in these cells [203]. Furthermore, atorvastatin and curcumin co-delivered by liposomes decreased E-selectin and ICAM-1 expression in dysfunctional human aortic endothelial cells (HAEC). When administered to Apoe-/- mice, this combination therapy reduced plasma lipid levels and reduced IL-6 expression in aortic artery samples [204]. Thus, several lines of evidence show that statins may prevent endothelial dysfunction by decreasing the expression of adhesion and inflammation molecules, although clinical studies are necessary to validate these results.

Anti-inflammatory drugs. Because atherosclerosis is a chronic inflammatory disease, novel anti-inflammatory drugs may be useful to prevent endothelial dysfunction and CAD. Tocilizumab is a monoclonal human antibody that blocks IL-6 receptors and is used as treatment for rheumatoid arthritis (RA). Bacchiega and colleagues completed a clinical trial in 18 patients with RA who received tocilizumab therapy for 4 weeks and found decreased CRP levels in blood [205]. Moreover, in an independent study with RA patients, tocilizumab treatment was found to increase endothelial glycocalyx thickness as measured by perfused boundary region and to reduce arterial stiffness [206]. However, although tocilizumab treatment improved markers of endothelial dysfunction, both studies reported increased lipid levels, a well-known risk factor for CAD.

The Janus kinase inhibitor tofacitinib was found to decrease VCAM-1, ICAM-1, TNF- $\alpha$ and IL-1 $\beta$ expression and increase cellular viability of oxLDL-stimulated HAEC [207]. Furthermore, the tyrosine kinase inhibitor imatinib was found to ameliorate endothelial dysfunction in rabbits fed a high cholesterol diet. In this model, imatinib treatment improved acetylcholine-induced relaxation of isolated rabbit aortic rings and increased aortic NO content. In addition, imatinib treatment decreased blood CRP and lipid levels [208]. Finally, zafirlukast is a potent anti-inflammatory mediator that blocks the type 1 cysteinyl leukotriene receptor (CysLT1R). Zafirlukast therapy was found to decrease ICAM-1, VCAM-1, IL-1, IL-6, and IL-8 expression, and to suppress TNF- $\alpha$-induced production of ROS in HAEC cells treated with TNF- $\alpha$, suggesting that zafirlukast treatment may eventually be used to decrease cardiovascular risk [209].

Antiplatelet drugs. Evidence from various studies show that antiplatelet drugs may prevent endothelial dysfunction by several mechanisms. Vorapaxar is an antagonist and protease-activated receptor 1 (PAR-1) inhibitor. In EC stimulated with cholesterol, PAR-1 inhibition significantly increased EC viability; decreased IL-1 $\beta$, IL-8 and TNF- $\alpha$ levels and increased IL-13 (anti-inflammatory interleukin) expression. Moreover, vorapaxar decreased 
DNA damage and increased eNOS expression via the AKT/JNK signaling pathway in these cells [210]. Ticagrelor is a P2Y12 inhibitor. In a study of patients with stable CAD and chronic obstructive pulmonary disease, ticagrelor combined with aspirin was found to better improve endothelial function parameters (apoptosis rate and NO levels in HUVEC treated with patient's serum, and intracellular ROS levels in peripheral blood mononuclear cells isolated from patients) as compared to clopidogrel and aspirin combined therapy [211]. Moreover, ticagrelor treatment decreased the circulating levels of epidermal growth factor (EGF), a marker of endothelial dysfunction. Serum of ticagrelor-treated patients was found to increase eNOS levels of HUVEC [212]. Shortly afterwards, peripheral blood cells from CAD patients with concomitant chronic obstructive pulmonary disease treated with ticagrelor showed decreased SIRT1 and HEAS1 mRNA expression (anti-inflammatory genes), which correlated negatively with EGF serum levels [213].

Others. The effects of the selective serotonin agonist (R)-2,5-dimethoxy-4-iodoamphetamine ((R)-DOI) were assessed in Apoe-/- mice fed with high fat diet. Sustained delivery of low-dose (R)-DOI decreased serum cholesterol levels and vcam-1, IL-6 and tnf- $\alpha$ gene expression in aorta arch of these mice, suggesting that (R)-DOI could counteract the proinflammatory effects induced by Western diet [214]. On the other hand, fenofibrate is a peroxisome proliferator-activated receptor alpha agonist widely used to treat mixed dyslipidemia. In mice with induced diabetes, fenofibrate treatment significantly ameliorated acetylcholine-induced endothelium dependent relaxation of mouse aortae. Furthermore, in mouse aortic endothelial cells cultured with high glucose, fenofibrate therapy increased NO production, decreased superoxide anion levels, and activated eNOS and adenosine monophosphate-activated protein kinase (AMPK) phosphorylation, suggesting that fenofibrate improves endothelial function [215].

Altogether, these drugs may be promising therapies to prevent proinflammatory state and endothelial dysfunction and stop development and progression of CAD; however, more clinical trials are required to ensure efficacy and safety.

\subsubsection{Non-Pharmacological Therapies Lifestyle Modifications}

Lifestyle plays a key role in the development of endothelial dysfunction and related diseases. An illustrative example is the increasing incidence of cardiovascular events and prevalence of overweight and metabolic syndrome (MS) in Japanese society by lifestyle westernization [216]. Given the influence of lifestyle, in addition to pharmacological intervention, conventional treatment of endothelial dysfunction includes lifestyle modification (exercise, diet and smoking). We describe here recent scientific evidence supporting the impact of lifestyle modification in patients with endothelial dysfunction and related disease.

Exercise. Currently, exercise is a well-recognized component of the integral therapy of cardiac rehabilitation and an effective element to restore endothelial function. Molecular effects of exercise training in patients with cardiac disease have been thoroughly investigated [217]. The effects of exercise training effects on endothelium function include increased eNOS and NO bioavailability, and reduced ROS [217]. In 2013, the American Heart Association (AHA) updated its exercise training guideline for suitable patients as an adjuvant to cardiac therapy. These standards are meant to be used by physicians, nurses and other health care professionals to treat patients with cardiovascular disease and other disease states [218]. Various exercise programs have improved endothelial function in patients with cardiovascular disease [219-221]. In men, regular exercise preserves vascular endothelial function with ageing; but in estrogen-deficient postmenopausal women the evidence is not consistent. However, there is evidence indicating that estradiol treatment restores the ability of exercise training to improve endothelial function in these women [222,223].

Diet. Many endothelial dysfunction-related diseases are associated with poor quality diet. These diseases include cardiovascular disease (CVD), T2DM, MS and obesity. Health organizations have been promoting dietary recommendations to reduce CVD risk [224-226]. The "2017 AHA presidential advisory on dietary fats and CVD" and the 
"2015 to 2020 Dietary Guidelines for Americans" draw attention to reducing the intake of low saturated fats and replacing it with unsaturated fats (particularly polyunsaturated fats), adopting a healthy eating pattern as the Mediterranean-style and Dietary Approaches to Stop Hypertension (DASH) $[224,226]$. The Mediterranean diet has been extensively studied and associated with a lower risk of all-cause mortality, cardiovascular disease, T2DM, and some types of cancer [227-232]. This diet is characterized by high consumption of vegetables, legumes, fruits, nuts, whole grains, fish, seafood, extra virgin olive oil, a moderate intake of red wine, low consumption of red and processed meat; as well as low consumption of sugar (sucrose), sweetened foods and drinks and refined grains [233]. Bioactive components of the Mediterranean diet include fiber, phytosterols, polyphenols, monounsaturated and polyunsaturated fats, vitamins and minerals [234], which provide its lipid-lowering, insulin-sensitizing, antioxidative, anti-inflammatory and antithrombotic properties [233].

Smoking. According to the World Health Organization global report on trends in prevalence of tobacco use 2000-2025 third edition, around 8 million people died from tobacco-related disease in 2017, and even though the smoking population is decreasing in developed countries, it is growing in developing countries [235]. Smoking is one of the major risk factors of cardiovascular diseases, and oxidative stress is the most likely underlying mechanism of smoking-induced endothelial dysfunction [236]. Even low cigarette consumption (1 cigarette per day) represents a risk factor for developing coronary heart disease and stroke [237]. While the use of electronic cigarettes was initially thought to be safe, a clinical study revealed that biomarkers for oxidative stress and flow-mediated dilatation were equally affected in both traditional and electronic cigarette smokers [238]. Moreover, the results of a systematic review and meta-analysis suggested that the electronic cigarettes should not be labelled as cardiovascular safe products [239]. However, nicotine replacement therapy can be of aid to restore endothelial function after smoking cessation [240].

\section{Antioxidant Therapy}

Endothelial dysfunction is a multifactorial disease, where ROS production is one of the mechanisms involved. ROS are synthetized in the endothelial cell layer, and within the media and adventitia. The imbalance of ROS synthesis and the antioxidant mechanisms in favor of ROS formation is the definition of oxidative stress [241]. Oxygen toxicity has an impact on all major organic molecules such as nucleic acids, proteins and free amino acids, lipids and carbohydrates. Molecular mechanisms involved in endothelial dysfunction by oxidative stress include the uncoupling of eNOS by reactive oxygen and nitrogen species, upregulation of ET-1 expression with subsequent production superoxide/hydrogen peroxide and activation of NADPH oxidase (Nox1 or Nox2) via angiotensin II [242-244]. Historically, antioxidative vitamin (C and E) administration has contributed to restore endothelial function and thus to decrease the risk of cardiovascular disease [242]. For example, high dose intravenous vitamin $\mathrm{C}$ restored blood flow during endotoxemia in healthy human subjects, presumably preventing NO inactivation by ROS [245]. On the other hand, endothelial dysfunction is characterized by decreased NO bioavailability, most likely originated by increased arginase activity. Several studies have focused on the effects of plant-derived compounds such as polyphenols (known to inhibit arginase activity), for the treatment of different endothelial dysfunction-induced diseases, mainly in animal models. Although clinical trials of these compounds are limited, they have shown promising results.

Animal models. Fauzy et al. [246] observed that treatment of hypertensive rats with an aqueous extract of the plant Piper sarmentosum, significantly reduced blood pressure. Mesenteric artery NO levels were increased and vasoconstrictor ET-1 were reduced after 28 days of treatment. Chemical constituents of Piper sarmentosum include quercetin, a flavonoid that modulates the ET- 1 and NO circulating levels, presumably via NADPH oxidase inhibition and eNOS activation. Furthermore, ginger is well known for its beneficial properties preventing cardiovascular disease. In order to identify the possible molecular mechanism underlying these properties, effects of aqueous extracts from two 
different ginger varieties (Zingiber officinale and Curcuma longa) were assessed in a highcholesterol-diet hypercholesterolemic animal model, characterized by increased arginase activity, atherogenic index and plasma lipid levels. Composition analysis of these extracts revealed the presence of several antioxidant compounds, including high concentrations of polyphenolic compounds. Rats with an extract supplemented-diet showed decreased plasma and liver arginase activity, atherogenic indices and plasma lipid levels. Authors proposed the mechanism was mediated by the antioxidant effects of polyphenols [247]. Likewise, 2,3,5,4'-tetrahydroxystilbene-2-O- $\beta$-D-glucoside (THSG), a compound extracted from the rhizome of Polygonum multiflorum with dose-dependent arginase inhibitory activity, showed increased NO synthesis and reduced ROS levels in the aortic endothelium of both wild-type and atherosclerosis-prone Apoe-/- mice [248].

Studies in Humans. Phyllanthus emblica fruit aqueous extracts were tested in a clinical trial of subjects with MS. Subjects who received the extract showed significant improved levels of endothelial dysfunction, oxidative stress and systemic inflammation, as well as lipid profiles. Previous reports showed that these extracts inhibit the production of lipid peroxide and is a scavenger of hydroxyl and superoxide radicals in vitro and in vivo [249]. Furthermore, these extracts improved endothelial function and reduced oxidative stress and systemic inflammation biomarkers in patients with T2DM [250,251].

In a randomized crossover clinical trial, pre-hypertensive patients (systolic blood pressure between 125- and 160-mm Hg) consumed pure flavonoids (a subclass of polyphenols) epicatechin and quercetin and serum biomarkers of endothelial dysfunction and inflammation were assessed at the end of the study. Epicatechin improved endothelial dysfunction with no effect on inflammation, whereas quercetin reversed endothelial dysfunction and reduced inflammation [252]. Another randomized, double-blind, cross-over, placebo-controlled clinical trial in hypertensive patients, showed gender differences in endothelial dysfunction by resveratrol intake. Only women presented a significant improvement in endothelial function, with no changes in blood pressure measurements in either gender. The authors suggested that this gender difference could be explained by lower levels of oxidative stress in women [253].

The goal of these studies was to find alternative treatments to restore endothelial function with minimal adverse effects. Since these plant-derived compounds have been used in traditional medicine as herbal therapy to treat several conditions including those related to endothelial dysfunction, they may represent a safe alternative that could be used as adjuvant or substitute of conventional drugs.

\section{Conclusions}

CAD is the most common form of heart disease. It is the result of atheromatous changes in the vessels supplying blood to the heart. CAD describes a range of clinical disorders from asymptomatic atherosclerosis and stable angina to acute coronary syndromes. The endothelium plays an important role in maintaining vascular homeostasis and regulating blood vessel function. Evidence supports the central role of endothelium and inflammation in all phases of the atherosclerotic process. It is now clear that inflammatory processes have a key role not only in the initiation and progression of atherosclerosis but also in the stability of the established atherosclerotic plaques. Early atherosclerotic lesions are reversible, and the use of liquid biopsies and new molecular biology techniques have allowed the identification of molecular and cellular markers of endothelial dysfunction such as EMPs, microRNAs, phospholipids and proteins that help establish an early diagnosis and may be targets to prevent endothelial dysfunction and CAD. Additionally, pharmacological and non-pharmacological therapeutical approaches can improve endothelial function, prevent atherosclerosis and CAD, and avoid its complications. 
Author Contributions: Conceptualization, L.J.-A. and D.J.M.-L.; D.J.M.-L., O.Z.-G., M.D.-P., A.G.-G. and L.J.-A. wrote and prepared the original draft; T.V.-M. reviewed and edited the manuscript. All authors have read and agreed to the published version of the manuscript.

Funding: This research received no external funding.

Institutional Review Board Statement: Not applicable.

Informed Consent Statement: Not applicable.

Acknowledgments: Thanks to Mariana Romo, Rebeca Pérez, Geovanni López and James González, teachers of science writing class who inspired to write this review and gave the tools to make so. All figures and graphical abstract were created with BioRender.com (accessed on 2 March 2021).

Conflicts of Interest: The authors declare no conflict of interest.

\section{References}

1. Las Principales Causas de Defunción OMS. 2018. Available online: https://www.who.int/es/news-room/fact-sheets/detail/th e-top-10-causes-of-death (accessed on 16 February 2019).

2. Gao, W.; Liu, H.; Yuan, J.; Wu, C.; Huang, D.; Ma, Y.; Zhu, J.; Ma, L.; Guo, J.; Shi, H.; et al. Exosomes derived from mature dendritic cells increase endothelial inflammation and atherosclerosis via membrane TNF-alpha mediated NF-kappaB pathway. J. Cell Mol. Med. 2016, 20, 2318-2327. [CrossRef] [PubMed]

3. Herrero-Fernandez, B.; Gomez-Bris, R.; Somovilla-Crespo, B.; Gonzalez-Granado, J.M. Immunobiology of Atherosclerosis: A Complex Net of Interactions. Int. J. Mol. Sci. 2019, 20, 5293. [CrossRef] [PubMed]

4. Marchio, P.; Guerra-Ojeda, S.; Vila, J.M.; Aldasoro, M.; Victor, V.M.; Mauricio, M.D. Targeting Early Atherosclerosis: A Focus on Oxidative Stress and Inflammation. Oxid. Med. Cell Longev. 2019, 2019, 8563845. [CrossRef] [PubMed]

5. Lee, D.-Y.; Chiu, J.-J. Atherosclerosis and flow: Roles of epigenetic modulation in vascular endothelium. J. Biomed. Sci. 2019, 26, 56. [CrossRef] [PubMed]

6. Strohbach, A.; Pennewitz, M.; Glaubitz, M.; Palankar, R.; Gross, S.; Lorenz, F.; Materzok, I.; Rong, A.; Busch, M.C.; Felix, S.B.; et al. The apelin receptor influences biomechanical and morphological properties of endothelial cells. J. Cell. Physiol. 2018, 233, 6250-6261. [CrossRef] [PubMed]

7. Boen, J.R.A.; Gevaert, A.B.; De Keulenaer, G.W.; Van Craenenbroeck, E.M.; Segers, V.F.M. The role of endothelial miRNAs in myocardial biology and disease. J. Mol. Cell. Cardiol. 2020, 138, 75-87. [CrossRef]

8. Sun, H.-J.; Wu, Z.-Y.; Nie, X.-W.; Bian, J.-S. Role of endothelial dysfunction in cardiovascular diseases: The link between inflammation and hydrogen sulfide. Front. Pharmacol. 2019, 10, 1568. [CrossRef]

9. Medina-Leyte, D.J.; Domínguez-Pérez, M.; Mercado, I.; Villarreal-Molina, M.T.; Jacobo-Albavera, L. Use of Human Umbilical Vein Endothelial Cells (HUVEC) as a Model to Study Cardiovascular Disease: A Review. Appl. Sci. 2020, 10, 938. [CrossRef]

10. Florey, L. The endothelial cell. Br. Med. J. 1966, 2, 487-490. [CrossRef] [PubMed]

11. Michiels, C. Endothelial cell functions. J. Cell. Physiol. 2003, 196, 430-443. [CrossRef]

12. Triggle, C.R.; Samuel, S.M.; Ravishankar, S.; Marei, I.; Arunachalam, G.; Ding, H. The endothelium: Influencing vascular smooth muscle in many ways. Can. J. Physiol. Pharmacol. 2012, 90, 713-738. [CrossRef] [PubMed]

13. Virchow, R. Der ateromatose prozess der arterien. Wien. Med. Wochenschr. 1856, 6, 825-827.

14. Gimbrone, M.A., Jr.; Alexander, R.W. Angiotensin II stimulation of prostaglandin production in cultured human vascular endothelium. Science 1975, 189, 219-220. [CrossRef]

15. Weksler, B.B.; Marcus, A.J.; Jaffe, E.A. Synthesis of prostaglandin I2 (prostacyclin) by cultured human and bovine endothelial cells. Proc. Natl. Acad. Sci. USA 1977, 74, 3922-3926. [CrossRef] [PubMed]

16. Moncada, S.; Herman, A.G.; Higgs, E.A.; Vane, J.R. Differential formation of prostacyclin (PGX or PGI2) by layers of the arterial wall. An explanation for the anti-thrombotic properties of vascular endothelium. Thromb. Res. 1977, 11, 323-344. [CrossRef]

17. Furchgott, R.F.; Zawadzki, J.V. The obligatory role of endothelial cells in the relaxation of arterial smooth muscle by acetylcholine. Nature 1980, 288, 373-376. [CrossRef] [PubMed]

18. Libby, P.; Ordovas, J.M.; Auger, K.R.; Robbins, A.H.; Birinyi, L.K.; Dinarello, C.A. Endotoxin and tumor necrosis factor induce interleukin-1 gene expression in adult human vascular endothelial cells. Am. J. Pathol. 1986, 124, 179-185. [PubMed]

19. Vane, J.R. The Croonian Lecture, 1993. The endothelium: Maestro of the blood circulation. Philos. Trans. R. Soc. Lond. B Biol. Sci. 1994, 343, 225-246. [PubMed]

20. Palmer, R.M.; Ferrige, A.G.; Moncada, S. Nitric oxide release accounts for the biological activity of endothelium-derived relaxing factor. Nature 1987, 327, 524-526. [CrossRef]

21. Fuchgott, R.F. Studies on relaxation of rabbit aorta by sodium nitrite: The basis for the proposal that the acid-activatable inhibitory factor from bovine retractor penis is inorganic nitrite and the endothelium-derived relaxing factor is nitric oxide. In Vasodilatation Vascular Smooth Muscle, Peptides Autonomic Nerves, and Endothelium; Vanhoutte, P., Ed.; Raven Press: New York City, NY, USA, 1988; pp. 401-414.

22. Komori, K.; Vanhoutte, P.M. Endothelium-derived hyperpolarizing factor. Blood Vessel. 1990, 27, 238-245. [CrossRef] 
23. Rubanyi, G.M.; Botelho, L.H. Endothelins. FASEB J. 1991, 5, 2713-2720. [CrossRef]

24. De Graaf, J.; Banga, J.; Moncada, S.; Palmer, R.; de Groot, P.; Sixma, J. Nitric oxide functions as an inhibitor of platelet adhesion under flow conditions. Circulation 1992, 85, 2284-2290. [CrossRef] [PubMed]

25. Schnittler, H.J. Structural and functional aspects of intercellular junctions in vascular endothelium. Basic Res. Cardiol. 1998, 93 (Suppl. 3), 30-39. [CrossRef] [PubMed]

26. Baldwin, A.L.; Thurston, G. Mechanics of endothelial cell architecture and vascular permeability. Crit. Rev. Biomed. Eng. 2001, 29, 247-278. [CrossRef] [PubMed]

27. Konukoglu, D.; Uzun, H. Endothelial dysfunction and hypertension. In Hypertension: From Basic Research to Clinical Practice; Springer: Berlin/Heidelberg, Germany, 2016; pp. 511-540.

28. Sandoo, A.; van Zanten, J.J.; Metsios, G.S.; Carroll, D.; Kitas, G.D. The endothelium and its role in regulating vascular tone. Open Cardiovasc. Med. J. 2010, 4, 302-312. [CrossRef] [PubMed]

29. Kruger-Genge, A.; Blocki, A.; Franke, R.P.; Jung, F. Vascular Endothelial Cell Biology: An Update. Int. J. Mol. Sci. $2019,20,4411$. [CrossRef] [PubMed]

30. Mundi, S.; Massaro, M.; Scoditti, E.; Carluccio, M.A.; van Hinsbergh, V.W.M.; Iruela-Arispe, M.L.; De Caterina, R. Endothelial permeability, LDL deposition, and cardiovascular risk factors-a review. Cardiovasc. Res. 2018, 114, 35-52. [CrossRef]

31. Lampugnani, M.G. Endothelial cell-to-cell junctions: Adhesion and signaling in physiology and pathology. Cold Spring Harb. Perspect. Med. 2012, 2, a006528. [CrossRef]

32. Pries, A.R.; Secomb, T.W.; Gaehtgens, P. The endothelial surface layer. Pflug. Arch. 2000, 440, 653-666. [CrossRef]

33. van den Berg, B.M.; Nieuwdorp, M.; Stroes, E.S.; Vink, H. Glycocalyx and endothelial (dys) function: From mice to men. Pharmacol. Rep. 2006, 58, 75-80. [PubMed]

34. Buonassisi, V. Sulfated mucopolysaccharide synthesis and secretion in endothelial cell cultures. Exp. Cell Res. 1973, 76, 363-368. [CrossRef]

35. Gerrity, R.G.; Richardson, M.; Somer, J.B.; Bell, F.P.; Schwartz, C.J. Endothelial cell morphology in areas of in vivo Evans blue uptake in the aorta of young pigs. II. Ultrastructure of the intima in areas of differing permeability to proteins. Am. J. Pathol. 1977, 89, 313-334.

36. Baldwin, A.L.; Winlove, C.P. Effects of perfusate composition on binding of ruthenium red and gold colloid to glycocalyx of rabbit aortic endothelium. J. Histochem. Cytochem. 1984, 32, 259-266. [CrossRef]

37. Simionescu, M.; Simionescu, N.; Palade, G.E. Segmental differentiations of cell junctions in the vascular endothelium. The microvasculature. J. Cell Biol. 1975, 67, 863-885. [CrossRef]

38. Dejana, E.; Corada, M.; Lampugnani, M.G. Endothelial cell-to-cell junctions. FASEB J. 1995, 9, 910-918. [CrossRef]

39. Simionescu, M.; Antohe, F. Functional ultrastructure of the vascular endothelium: Changes in various pathologies. In The Vascular Endothelium I; Springer: Berlin/Heidelberg, Germany, 2006; pp. 41-69.

40. Nieuwdorp, M.; Meuwese, M.C.; Vink, H.; Hoekstra, J.B.; Kastelein, J.J.; Stroes, E.S. The endothelial glycocalyx: A potential barrier between health and vascular disease. Curr. Opin. Lipidol. 2005, 16, 507-511. [CrossRef]

41. Zhang, X.; Sessa, W.C.; Fernandez-Hernando, C. Endothelial Transcytosis of Lipoproteins in Atherosclerosis. Front. Cardiovasc. Med. 2018, 5, 130. [CrossRef] [PubMed]

42. Mehta, D.; Malik, A.B. Signaling mechanisms regulating endothelial permeability. Physiol. Rev. 2006, 86, 279-367. [CrossRef]

43. Rahimi, N. Defenders and Challengers of Endothelial Barrier Function. Front. Immunol. 2017, 8, 1847. [CrossRef] [PubMed]

44. Fung, K.Y.Y.; Fairn, G.D.; Lee, W.L. Transcellular vesicular transport in epithelial and endothelial cells: Challenges and opportunities. Traffic 2018, 19, 5-18. [CrossRef]

45. Armstrong, S.M.; Sugiyama, M.G.; Fung, K.Y.; Gao, Y.; Wang, C.; Levy, A.S.; Azizi, P.; Roufaiel, M.; Zhu, S.N.; Neculai, D.; et al. A novel assay uncovers an unexpected role for SR-BI in LDL transcytosis. Cardiovasc. Res. 2015, 108, 268-277. [CrossRef]

46. Rohrer, L.; Cavelier, C.; Fuchs, S.; Schlüter, M.A.; Völker, W.; von Eckardstein, A. Binding, internalization and transport of apolipoprotein AI by vascular endothelial cells. Biochim. Biophys. Acta (BBA)-Mol. Cell Biol. Lipids 2006, 1761, 186-194. [CrossRef]

47. Cavelier, C.; Rohrer, L.; Von Eckardstein, A. ATP-Binding cassette transporter A1 modulates apolipoprotein AI transcytosis through aortic endothelial cells. Circ. Res. 2006, 99, 1060-1066. [CrossRef]

48. Vaisman, B.L.; Demosky, S.J.; Stonik, J.A.; Ghias, M.; Knapper, C.L.; Sampson, M.L.; Dai, C.; Levine, S.J.; Remaley, A.T. Endothelial expression of human ABCA1 in mice increases plasma HDL cholesterol and reduces diet-induced atherosclerosis. J. Lipid Res. 2012, 53, 158-167. [CrossRef] [PubMed]

49. Westerterp, M.; Tsuchiya, K.; Tattersall, I.W.; Fotakis, P.; Bochem, A.E.; Molusky, M.M.; Ntonga, V.; Abramowicz, S.; Parks, J.S.; Welch, C.L.; et al. Deficiency of ATP-Binding Cassette Transporters A1 and G1 in Endothelial Cells Accelerates Atherosclerosis in Mice. Arterioscler. Thromb. Vasc. Biol. 2016, 36, 1328-1337. [CrossRef] [PubMed]

50. Stamatikos, A.; Dronadula, N.; Ng, P.; Palmer, D.; Knight, E.; Wacker, B.K.; Tang, C.; Kim, F.; Dichek, D.A. ABCA1 Overexpression in Endothelial Cells In Vitro Enhances ApoAI-Mediated Cholesterol Efflux and Decreases Inflammation. Hum. Gene Ther. 2019, 30, 236-248. [CrossRef]

51. Rajendran, P.; Rengarajan, T.; Thangavel, J.; Nishigaki, Y.; Sakthisekaran, D.; Sethi, G.; Nishigaki, I. The vascular endothelium and human diseases. Int. J. Biol. Sci. 2013, 9, 1057-1069. [CrossRef] [PubMed]

52. van Hinsbergh, V.W. Endothelium-Role in Regulation of Coagulation and Inflammation. In Seminars in Immunopathology; Springer: Berlin/Heidelberg, Germany, 2012; pp. 93-106. 
53. Kirsch, J.; Schneider, H.; Pagel, J.-I.; Rehberg, M.; Singer, M.; Hellfritsch, J.; Chillo, O.; Schubert, K.M.; Qiu, J.; Pogoda, K. Endothelial dysfunction, and a prothrombotic, proinflammatory phenotype is caused by loss of mitochondrial thioredoxin reductase in endothelium. Arterioscler. Thromb. Vasc. Biol. 2016, 36, 1891-1899. [CrossRef]

54. Lin, J.; He, S.; Sun, X.; Franck, G.; Deng, Y.; Yang, D.; Haemmig, S.; Wara, A.K.; Icli, B.; Li, D.; et al. MicroRNA-181b inhibits thrombin-mediated endothelial activation and arterial thrombosis by targeting caspase recruitment domain family member 10. FASEB J. 2016, 30, 3216-3226. [CrossRef]

55. Yau, J.W.; Singh, K.K.; Hou, Y.; Lei, X.; Ramadan, A.; Quan, A.; Teoh, H.; Kuebler, W.M.; Al-Omran, M.; Yanagawa, B.; et al. Endothelial-specific deletion of autophagy-related 7 (ATG7) attenuates arterial thrombosis in mice. J. Thorac. Cardiovasc. Surg. 2017, 154, 978-988.e1. [CrossRef]

56. Wu, Q.; Hu, Y.; Jiang, M.; Wang, F.; Gong, G. Effect of Autophagy Regulated by Sirt1/FoxO1 Pathway on the Release of Factors Promoting Thrombosis from Vascular Endothelial Cells. Int. J. Mol. Sci. 2019, 20, 4132. [CrossRef] [PubMed]

57. Segal, S.S. Regulation of blood flow in the microcirculation. Microcirculation 2005, 12, 33-45. [CrossRef] [PubMed]

58. Khaddaj Mallat, R.; Mathew John, C.; Kendrick, D.J.; Braun, A.P. The vascular endothelium: A regulator of arterial tone and interface for the immune system. Crit. Rev. Clin. Lab. Sci. 2017, 54, 458-470. [CrossRef]

59. Heathcote, H.R.; Lee, M.D.; Zhang, X.; Saunter, C.D.; Wilson, C.; McCarron, J.G. Endothelial TRPV4 channels modulate vascular tone by $\mathrm{Ca}(2+)$-induced $\mathrm{Ca}(2+)$ release at inositol 1,4,5-trisphosphate receptors. Br. J. Pharmacol. 2019, 176, 3297-3317. [CrossRef]

60. Iring, A.; Jin, Y.J.; Albarran-Juarez, J.; Siragusa, M.; Wang, S.; Dancs, P.T.; Nakayama, A.; Tonack, S.; Chen, M.; Kunne, C.; et al Shear stress-induced endothelial adrenomedullin signaling regulates vascular tone and blood pressure. J. Clin. Investig. 2019, 129, 2775-2791. [CrossRef] [PubMed]

61. Nafisa, A.; Gray, S.G.; Cao, Y.; Wang, T.; Xu, S.; Wattoo, F.H.; Barras, M.; Cohen, N.; Kamato, D.; Little, P.J. Endothelial function and dysfunction: Impact of metformin. Pharmacol. Ther. 2018, 192, 150-162. [CrossRef]

62. Silva, I.V.G.; de Figueiredo, R.C.; Rios, D.R.A. Effect of Different Classes of Antihypertensive Drugs on Endothelial Function and Inflammation. Int. J. Mol. Sci. 2019, 20, 3458. [CrossRef]

63. Pober, J.S.; Sessa, W.C. Evolving functions of endothelial cells in inflammation. Nat. Rev. Immunol. 2007, 7, 803-815. [CrossRef]

64. Osman, R.; L'Allier, P.L.; Elgharib, N.; Tardif, J.C. Critical appraisal of C-reactive protein throughout the spectrum of cardiovascular disease. Vasc. Health Risk Manag. 2006, 2, 221-237. [CrossRef]

65. Incalza, M.A.; D'Oria, R.; Natalicchio, A.; Perrini, S.; Laviola, L.; Giorgino, F. Oxidative stress and reactive oxygen species in endothelial dysfunction associated with cardiovascular and metabolic diseases. Vascul. Pharmacol. 2018, 100, 1-19. [CrossRef]

66. Scioli, M.G.; Storti, G.; D’Amico, F.; Rodriguez Guzman, R.; Centofanti, F.; Doldo, E.; Cespedes Miranda, E.M.; Orlandi, A. Oxidative Stress and New Pathogenetic Mechanisms in Endothelial Dysfunction: Potential Diagnostic Biomarkers and Therapeutic Targets. J. Clin. Med. 2020, 9, 1995. [CrossRef] [PubMed]

67. Ho, E.; Karimi Galougahi, K.; Liu, C.C.; Bhindi, R.; Figtree, G.A. Biological markers of oxidative stress: Applications to cardiovascular research and practice. Redox Biol. 2013, 483-491. [CrossRef] [PubMed]

68. Victor, V.M.; Rocha, M.; Sola, E.; Banuls, C.; Garcia-Malpartida, K.; Hernandez-Mijares, A. Oxidative stress, endothelial dysfunction and atherosclerosis. Curr. Pharm. Des. 2009, 15, 2988-3002. [CrossRef] [PubMed]

69. Lorenzon Dos Santos, J.; Quadros, A.S.; Weschenfelder, C.; Garofallo, S.B.; Marcadenti, A. Oxidative Stress Biomarkers, NutRelated Antioxidants, and Cardiovascular Disease. Nutrients 2020, 12, 682. [CrossRef] [PubMed]

70. Goncharov, N.V.; Nadeev, A.D.; Jenkins, R.O.; Avdonin, P.V. Markers and biomarkers of endothelium: When something is rotten in the state. Oxid. Med. Cell Longev. 2017, 2017. [CrossRef] [PubMed]

71. Higashi, Y.; Maruhashi, T.; Noma, K.; Kihara, Y. Oxidative stress and endothelial dysfunction: Clinical evidence and therapeutic implications. Trends Cardiovasc. Med. 2014, 24, 165-169. [CrossRef]

72. Ito, F.; Sono, Y.; Ito, T. Measurement and clinical significance of lipid peroxidation as a biomarker of oxidative stress: Oxidative stress in diabetes, atherosclerosis, and chronic inflammation. Antioxidants 2019, 8, 72. [CrossRef]

73. Jenny, N.S.; Olson, N.C.; Allison, M.A.; Rifkin, D.E.; Daniels, L.B.; de Boer, I.H.; Wassel, C.L.; Tracy, R.P. Biomarkers of Key Biological Pathways in CVD. Glob. Heart 2016, 11, 327-336 e3. [CrossRef]

74. Kura, B.; Szeiffova Bacova, B.; Kalocayova, B.; Sykora, M.; Slezak, J. Oxidative Stress-Responsive MicroRNAs in Heart Injury. Int. J. Mol. Sci. 2020, 21, 358. [CrossRef]

75. Lyngbakken, M.N.; Myhre, P.L.; Rosjo, H.; Omland, T. Novel biomarkers of cardiovascular disease: Applications in clinical practice. Crit. Rev. Clin. Lab. Sci. 2019, 56, 33-60. [CrossRef]

76. Ruparelia, N.; Choudhury, R. Inflammation and atherosclerosis: What is on the horizon? Heart 2020, 106, 80-85. [CrossRef]

77. Antoniades, C.; Demosthenous, M.; Tousoulis, D.; Antonopoulos, A.S.; Vlachopoulos, C.; Toutouza, M.; Marinou, K.; Bakogiannis, C.; Mavragani, K.; Lazaros, G.; et al. Role of asymmetrical dimethylarginine in inflammation-induced endothelial dysfunction in human atherosclerosis. Hypertension 2011, 58, 93-98. [CrossRef]

78. Kharbanda, R.K.; Walton, B.; Allen, M.; Klein, N.; Hingorani, A.D.; MacAllister, R.J.; Vallance, P. Prevention of inflammationinduced endothelial dysfunction: A novel vasculo-protective action of aspirin. Circulation 2002, 105, 2600-2604. [CrossRef]

79. Vanhoutte, P.M.; Shimokawa, H.; Feletou, M.; Tang, E.H. Endothelial dysfunction and vascular disease-A 30th anniversary update. Acta Physiol. 2017, 219, 22-96. [CrossRef] [PubMed] 
80. Verma, S.; Wang, C.H.; Li, S.H.; Dumont, A.S.; Fedak, P.W.; Badiwala, M.V.; Dhillon, B.; Weisel, R.D.; Li, R.K.; Mickle, D.A.; et al. A self-fulfilling prophecy: C-reactive protein attenuates nitric oxide production and inhibits angiogenesis. Circulation 2002, 106, 913-919. [CrossRef] [PubMed]

81. Pasceri, V.; Willerson, J.T.; Yeh, E.T. Direct proinflammatory effect of C-reactive protein on human endothelial cells. Circulation 2000, 102, 2165-2168. [CrossRef] [PubMed]

82. Bisoendial, R.J.; Boekholdt, S.M.; Vergeer, M.; Stroes, E.S.; Kastelein, J.J. C-reactive protein is a mediator of cardiovascular disease. Eur. Heart J. 2010, 31, 2087-2091. [CrossRef]

83. Sara, J.D.S.; Prasad, M.; Zhang, M.; Lennon, R.J.; Herrmann, J.; Lerman, L.O.; Lerman, A. High-sensitivity C-reactive protein is an independent marker of abnormal coronary vasoreactivity in patients with non-obstructive coronary artery disease. Am. Heart $J$. 2017, 190, 1-11. [CrossRef]

84. Ridker, P.M.; MacFadyen, J.G.; Glynn, R.J.; Bradwin, G.; Hasan, A.A.; Rifai, N. Comparison of interleukin-6, C-reactive protein, and low-density lipoprotein cholesterol as biomarkers of residual risk in contemporary practice: Secondary analyses from the Cardiovascular Inflammation Reduction Trial. Eur. Heart J. 2020, 41, 2952-2961. [CrossRef]

85. Luyendyk, J.P.; Schoenecker, J.G.; Flick, M.J. The multifaceted role of fibrinogen in tissue injury and inflammation. Blood 2019, 133, 511-520. [CrossRef]

86. Danik, J.S.; Pare, G.; Chasman, D.I.; Zee, R.Y.; Kwiatkowski, D.J.; Parker, A.; Miletich, J.P.; Ridker, P.M. Novel loci, including those related to Crohn disease, psoriasis, and inflammation, identified in a genome-wide association study of fibrinogen in 17686 women: The Women's Genome Health Study. Circ. Cardiovasc. Genet. 2009, 2, 134-141. [CrossRef] [PubMed]

87. Yarnell, J.; McCrum, E.; Rumley, A.; Patterson, C.; Salomaa, V.; Lowe, G.; Evans, A. Association of European population levels of thrombotic and inflammatory factors with risk of coronary heart disease: The Monica Optional Haemostasis Study. Eur. Heart J. 2005, 26, 332-342. [CrossRef]

88. Reinhart, W.H. Fibrinogen-marker or mediator of vascular disease? Vasc. Med. 2003, 8, 211-216. [CrossRef]

89. Papageorgiou, N.; Tousoulis, D.; Siasos, G.; Stefanadis, C. Is fibrinogen a marker of inflammation in coronary artery disease. Hellenic. J. Cardiol. 2010, 51, 1-9.

90. Tousoulis, D.; Papageorgiou, N.; Androulakis, E.; Briasoulis, A.; Antoniades, C.; Stefanadis, C. Fibrinogen and cardiovascular disease: Genetics and biomarkers. Blood Rev. 2011, 25, 239-245. [CrossRef]

91. Buljubasic, N.; Akkerhuis, K.M.; Cheng, J.M.; Oemrawsingh, R.M.; Garcia-Garcia, H.M.; de Boer, S.P.; Regar, E.; van Geuns, R.M.; Serruys, P.W.; Boersma, E.; et al. Fibrinogen in relation to degree and composition of coronary plaque on intravascular ultrasound in patients undergoing coronary angiography. Coron. Artery Dis. 2017, 28, 23-32. [CrossRef]

92. Han, K.; Lu, Q.; Zhu, W.J.; Wang, T.Z.; Du, Y.; Bai, L. Correlations of degree of coronary artery stenosis with blood lipid, CRP, Hcy, GGT, SCD36 and fibrinogen levels in elderly patients with coronary heart disease. Eur. Rev. Med. Pharmacol. Sci. 2019, 23, 9582-9589. [PubMed]

93. Wang, J.; Jia, L.; Li, X.; Jin, S.; Li, X.; Liu, F.; Shan, C.; Zhang, Y.; Yang, Y. New Insights into the Association between Fibrinogen and Coronary Atherosclerotic Plaque Vulnerability: An Intravascular Optical Coherence Tomography Study. Cardiovasc. Ther. 2019, 2019, 8563717. [CrossRef] [PubMed]

94. Tabakci, M.M.; Gerin, F.; Sunbul, M.; Toprak, C.; Durmus, H.I.; Demir, S.; Arslantas, U.; Cersit, S.; Batgerel, U.; Kargin, R. Relation of Plasma Fibrinogen Level with the Presence, Severity, and Complexity of Coronary Artery Disease. Clin. Appl. Thromb. Hemost. 2017, 23, 638-644. [CrossRef] [PubMed]

95. Peng, Y.; Wang, H.; Li, Y.M.; Huang, B.T.; Huang, F.Y.; Xia, T.L.; Chai, H.; Wang, P.J.; Liu, W.; Zhang, C.; et al. Relation between admission plasma fibrinogen levels and mortality in Chinese patients with coronary artery disease. Sci. Rep. 2016, 6, 30506. [CrossRef]

96. Lovely, R.S.; Falls, L.A.; Al-Mondhiry, H.A.; Chambers, C.E.; Sexton, G.J.; Ni, H.; Farrell, D.H. Association of $\gamma$ A $/ \gamma^{\prime}$ fibrinogen levels and coronary artery disease. Thromb. Haemost. 2002, 88, 26-31. [CrossRef]

97. Mannila, M.N.; Lovely, R.; Kazmierczak, S.; Eriksson, P.; Samnegård, A.; Farrell, D.; Hamsten, A.; Silveira, A. Elevated plasma fibrinogen $\gamma^{\prime}$ concentration is associated with myocardial infarction: Effects of variation in fibrinogen genes and environmental factors. J. Thromb. Haemost. 2007, 5, 766-773. [CrossRef] [PubMed]

98. Cheung, E.Y.; Uitte de Willige, S.; Vos, H.L.; Leebeek, F.W.; Dippel, D.W.; Bertina, R.M.; de Maat, M.P. Fibrinogen gamma' in ischemic stroke: A case-control study. Stroke 2008, 39, 1033-1035. [CrossRef] [PubMed]

99. Appiah, D.; Schreiner, P.J.; MacLehose, R.F.; Folsom, A.R. Association of Plasma gamma' Fibrinogen with Incident Cardiovascular Disease: The Atherosclerosis Risk in Communities (ARIC) Study. Arterioscler. Thromb. Vasc. Biol. 2015, 35, 2700-2706. [CrossRef] [PubMed]

100. Shridas, P.; Tannock, L.R. Role of serum amyloid A in atherosclerosis. Curr. Opin. Lipidol. 2019, 30, 320-325. [CrossRef] [PubMed]

101. Harb, T.S.; Zareba, W.; Moss, A.J.; Ridker, P.M.; Marder, V.J.; Rifai, N.; Miller Watelet, L.F.; Arora, R.; Brown, M.W.; Case, R.B.; et al. Association of C-reactive protein and serum amyloid A with recurrent coronary events in stable patients after healing of acute myocardial infarction. Am. J. Cardiol. 2002, 89, 216-221. [CrossRef]

102. Johnson, B.D.; Kip, K.E.; Marroquin, O.C.; Ridker, P.M.; Kelsey, S.F.; Shaw, L.J.; Pepine, C.J.; Sharaf, B.; Bairey Merz, C.N.; Sopko, G.; et al. Serum amyloid A as a predictor of coronary artery disease and cardiovascular outcome in women: The National Heart, Lung, and Blood Institute-Sponsored Women's Ischemia Syndrome Evaluation (WISE). Circulation 2004, 109, 726-732. [CrossRef] 
103. Ogasawara, K.; Mashiba, S.; Wada, Y.; Sahara, M.; Uchida, K.; Aizawa, T.; Kodama, T. A serum amyloid A and LDL complex as a new prognostic marker in stable coronary artery disease. Atherosclerosis 2004, 174, 349-356. [CrossRef]

104. Chang, C.; Pan, Y.; Du, H.; Wang, X.; Li, X. Serum amyloid A1 can be a novel biomarker for evaluating the presence and severity of acute coronary syndrome. Clin. Biochem. 2020, 85, 27-32. [CrossRef]

105. Kalsch, A.I.; Scharnagl, H.; Kleber, M.E.; Windpassinger, C.; Sattler, W.; Leipe, J.; Kramer, B.K.; Marz, W.; Malle, E. Long- and short-term association of low-grade systemic inflammation with cardiovascular mortality in the LURIC study. Clin. Res. Cardiol. 2020, 109, 358-373. [CrossRef] [PubMed]

106. Idriss, H.T.; Naismith, J.H. TNF $\alpha$ and the TNF receptor superfamily: Structure-function relationship (s). Microsc. Res. Tech. 2000, 50, 184-195. [CrossRef]

107. Zhang, H.; Park, Y.; Wu, J.; Chen, X.; Lee, S.; Yang, J.; Dellsperger, K.C.; Zhang, C. Role of TNF-alpha in vascular dysfunction. Clin. Sci. 2009, 116, 219-230. [CrossRef] [PubMed]

108. Naya, M.; Tsukamoto, T.; Morita, K.; Katoh, C.; Furumoto, T.; Fujii, S.; Tamaki, N.; Tsutsui, H. Plasma interleukin-6 and tumor necrosis factor- $\alpha$ can predict coronary endothelial dysfunction in hypertensive patients. Hypertens. Res. 2007, 30, 541-548. [CrossRef] [PubMed]

109. Skoog, T.; Dichtl, W.; Boquist, S.; Skoglund-Andersson, C.; Karpe, F.; Tang, R.; Bond, M.G.; de Faire, U.; Nilsson, J.; Eriksson, P.; et al. Plasma tumour necrosis factor-alpha and early carotid atherosclerosis in healthy middle-aged men. Eur. Heart J. 2002, 23, 376-383. [CrossRef] [PubMed]

110. Kaptoge, S.; Seshasai, S.R.; Gao, P.; Freitag, D.F.; Butterworth, A.S.; Borglykke, A.; Di Angelantonio, E.; Gudnason, V.; Rumley, A.; Lowe, G.D.; et al. Inflammatory cytokines and risk of coronary heart disease: New prospective study and updated meta-analysis. Eur. Heart J. 2014, 35, 578-589. [CrossRef] [PubMed]

111. Safranow, K.; Dziedziejko, V.; Rzeuski, R.; Czyzycka, E.; Wojtarowicz, A.; Binczak-Kuleta, A.; Jakubowska, K.; Olszewska, M.; Ciechanowicz, A.; Kornacewicz-Jach, Z.; et al. Plasma concentrations of TNF-alpha and its soluble receptors sTNFR1 and sTNFR2 in patients with coronary artery disease. Tissue Antigens 2009, 74, 386-392. [CrossRef] [PubMed]

112. Zhu, M.; Lei, L.; Zhu, Z.; Li, Q.; Guo, D.; Xu, J.; Chen, J.; Sha, H.; Zhang, X.; Yang, X.; et al. Excess TNF-alpha in the blood activates monocytes with the potential to directly form cholesteryl ester-laden cells. Acta Biochim. Biophys. Sin. 2015, 47, 899-907. [CrossRef] [PubMed]

113. Duan, H.O.; Simpson-Haidaris, P.J. Functional analysis of interleukin 6 response elements (IL-6REs) on the human gammafibrinogen promoter: Binding of hepatic Stat3 correlates negatively with transactivation potential of type II IL-6REs. J. Biol. Chem. 2003, 278, 41270-41281. [CrossRef]

114. Teixeira, B.C.; Lopes, A.L.; Macedo, R.C.O.; Correa, C.S.; Ramis, T.R.; Ribeiro, J.L.; Reischak-Oliveira, A. Inflammatory markers, endothelial function and cardiovascular risk. J. Vasc. Bras. 2014, 13, 108-115. [CrossRef]

115. Koyama, K.; Yoneyama, K.; Mitarai, T.; Ishibashi, Y.; Takahashi, E.; Kongoji, K.; Harada, T.; Akashi, Y.J. Association between inflammatory biomarkers and thin-cap fibroatheroma detected by optical coherence tomography in patients with coronary heart disease. Arch. Med. Sci. 2015, 11, 505-512. [CrossRef] [PubMed]

116. Held, C.; White, H.D.; Stewart, R.A.H.; Budaj, A.; Cannon, C.P.; Hochman, J.S.; Koenig, W.; Siegbahn, A.; Steg, P.G.; Soffer, J.; et al. Inflammatory Biomarkers Interleukin-6 and C-Reactive Protein and Outcomes in Stable Coronary Heart Disease: Experiences from the STABILITY (Stabilization of Atherosclerotic Plaque by Initiation of Darapladib Therapy) Trial. J. Am. Heart Assoc. 2017, 6, e005077. [CrossRef]

117. Boekholdt, S.M.; Peters, R.J.; Hack, C.E.; Day, N.E.; Luben, R.; Bingham, S.A.; Wareham, N.J.; Reitsma, P.H.; Khaw, K.T. IL-8 plasma concentrations and the risk of future coronary artery disease in apparently healthy men and women: The EPIC-Norfolk prospective population study. Arterioscler. Thromb. Vasc. Biol. 2004, 24, 1503-1508. [CrossRef]

118. Kanda, T.; Hirao, Y.; Oshima, S.; Yuasa, K.; Taniguchi, K.; Nagai, R.; Kobayashi, I. Interleukin-8 as a sensitive marker of unstable coronary artery disease. Am. J. Cardiol. 1996, 77, 304-307. [CrossRef]

119. Romuk, E.; Skrzep-Poloczek, B.; Wojciechowska, C.; Tomasik, A.; Birkner, E.; Wodniecki, J.; Gabrylewicz, B.; Ochala, A.; Tendera, M. Selectin-P and interleukin-8 plasma levels in coronary heart disease patients. Eur. J. Clin. Investig. 2002, 32, 657-661. [CrossRef] [PubMed]

120. Inoue, T.; Komoda, H.; Nonaka, M.; Kameda, M.; Uchida, T.; Node, K. Interleukin-8 as an independent predictor of long-term clinical outcome in patients with coronary artery disease. Int. J. Cardiol. 2008, 124, 319-325. [CrossRef]

121. Yasuda, K.; Nakanishi, K.; Tsutsui, H. Interleukin-18 in Health and Disease. Int. J. Mol. Sci. 2019, 20, 649. [CrossRef]

122. Mallat, Z.; Corbaz, A.; Scoazec, A.; Besnard, S.; Leseche, G.; Chvatchko, Y.; Tedgui, A. Expression of interleukin-18 in human atherosclerotic plaques and relation to plaque instability. Circulation 2001, 104, 1598-1603. [CrossRef] [PubMed]

123. Hulthe, J.; McPheat, W.; Samnegard, A.; Tornvall, P.; Hamsten, A.; Eriksson, P. Plasma interleukin (IL)- 18 concentrations is elevated in patients with previous myocardial infarction and related to severity of coronary atherosclerosis independently of C-reactive protein and IL-6. Atherosclerosis 2006, 188, 450-454. [CrossRef]

124. Blankenberg, S.; Tiret, L.; Bickel, C.; Peetz, D.; Cambien, F.; Meyer, J.; Rupprecht, H.J.; AtheroGene, I. Interleukin-18 is a strong predictor of cardiovascular death in stable and unstable angina. Circulation 2002, 106, 24-30. [CrossRef] [PubMed]

125. Jin, D.Y.; Liu, C.L.; Tang, J.N.; Zhu, Z.Z.; Xuan, X.X.; Zhu, X.D.; Wang, Y.Z.; Zhang, T.X.; Shen, D.L.; Wang, X.F.; et al. Interleukin-18, matrix metalloproteinase-22 and -29 are independent risk factors of human coronary heart disease. J. Zhejiang Univ. Sci. B 2017, 18, 685-695. [CrossRef] 
126. Blankenberg, S.; Luc, G.; Ducimetiere, P.; Arveiler, D.; Ferrieres, J.; Amouyel, P.; Evans, A.; Cambien, F.; Tiret, L.; Group, P.S. Interleukin-18 and the risk of coronary heart disease in European men: The Prospective Epidemiological Study of Myocardial Infarction (PRIME). Circulation 2003, 108, 2453-2459. [CrossRef] [PubMed]

127. Jefferis, B.J.; Papacosta, O.; Owen, C.G.; Wannamethee, S.G.; Humphries, S.E.; Woodward, M.; Lennon, L.T.; Thomson, A.; Welsh, P.; Rumley, A.; et al. Interleukin 18 and coronary heart disease: Prospective study and systematic review. Atherosclerosis 2011, 217, 227-233. [CrossRef]

128. Liu, K.; Tang, Q.; Zhu, X.; Yang, X. IL-37 increased in patients with acute coronary syndrome and associated with a worse clinical outcome after ST-segment elevation acute myocardial infarction. Clin. Chim. Acta 2017, 468, 140-144. [CrossRef] [PubMed]

129. Semaan, H.B.; Gurbel, P.A.; Anderson, J.L.; Muhlestein, J.B.; Carlquist, J.F.; Horne, B.D.; Serebruany, V.L. Soluble VCAM-1 and E-selectin, but not ICAM-1 discriminate endothelial injury in patients with documented coronary artery disease. Cardiology 2000, 93, 7-10. [CrossRef]

130. Leite, A.R.; Borges-Canha, M.; Cardoso, R.; Neves, J.S.; Castro-Ferreira, R.; Leite-Moreira, A. Novel Biomarkers for Evaluation of Endothelial Dysfunction. Angiology 2020, 71, 397-410. [CrossRef] [PubMed]

131. Peter, K.; Nawroth, P.; Conradt, C.; Nordt, T.; Weiss, T.; Boehme, M.; Wunsch, A.; Allenberg, J.; Kubler, W.; Bode, C. Circulating vascular cell adhesion molecule-1 correlates with the extent of human atherosclerosis in contrast to circulating intercellular adhesion molecule-1, E-selectin, P-selectin, and thrombomodulin. Arterioscler. Thromb. Vasc. Biol. 1997, 17, 505-512. [CrossRef] [PubMed]

132. Mulvihill, N.; Foley, J.; Murphy, R.; Curtin, R.; Crean, P.; Walsh, M. Risk stratification in unstable angina and non-Q wave myocardial infarction using soluble cell adhesion molecules. Heart 2001, 85, 623-627. [CrossRef]

133. Blankenberg, S.; Rupprecht, H.J.; Bickel, C.; Peetz, D.; Hafner, G.; Tiret, L.; Meyer, J. Circulating cell adhesion molecules and death in patients with coronary artery disease. Circulation 2001, 104, 1336-1342. [CrossRef]

134. Hillis, G.S.; Terregino, C.; Taggart, P.; Killian, A.; Zhao, N.; Dalsey, W.C.; Mangione, A. Elevated soluble P-selectin levels are associated with an increased risk of early adverse events in patients with presumed myocardial ischemia. Am. Heart J. 2002, 143, 235-241. [CrossRef] [PubMed]

135. Nasuno, A.; Matsubara, T.; Hori, T.; Higuchi, K.; Imai, S.; Nakagawa, I.; Tsuchida, K.; Ozaki, K.; Mezaki, T.; Tanaka, T.; et al. Levels of soluble E-selectin and ICAM-1 in the coronary circulation of patients with stable coronary artery disease: Association with the severity of coronary atherosclerosis. Jpn. Heart J. 2002, 43, 93-101. [CrossRef]

136. Haim, M.; Tanne, D.; Boyko, V.; Reshef, T.; Goldbourt, U.; Leor, J.; Mekori, Y.A.; Behar, S. Soluble intercellular adhesion molecule-1 and long-term risk of acute coronary events in patients with chronic coronary heart disease. Data from the Bezafibrate Infarction Prevention (BIP) Study. J. Am. Coll. Cardiol. 2002, 39, 1133-1138. [CrossRef]

137. Schumacher, A.; Seljeflot, I.; Sommervoll, L.; Christensen, B.; Otterstad, J.E.; Arnesen, H. Increased levels of markers of vascular inflammation in patients with coronary heart disease. Scand. J. Clin. Lab. Investig. 2002, 62, 59-68. [CrossRef]

138. Rallidis, L.S.; Gika, H.I.; Zolindaki, M.G.; Xydas, T.A.; Paravolidakis, K.E.; Velissaridou, A.H. Usefulness of elevated levels of soluble vascular cell adhesion molecule- 1 in predicting in-hospital prognosis in patients with unstable angina pectoris. Am. J. Cardiol. 2003, 92, 1195-1197. [CrossRef]

139. Jha, H.C.; Divya, A.; Prasad, J.; Mittal, A. Plasma circulatory markers in male and female patients with coronary artery disease. Heart Lung 2010, 39, 296-303. [CrossRef]

140. Liang, K.W.; Sheu, W.H.; Lee, W.J.; Lee, W.L.; Fu, C.P.; Wang, J.S. Differential expression of circulating vascular cell adhesion molecule- 1 in subjects with coronary artery disease and cardiac syndrome $X$ without known diabetes mellitus. Biomarkers 2017, 22, 798-804. [CrossRef]

141. Nozaki, T.; Sugiyama, S.; Koga, H.; Sugamura, K.; Ohba, K.; Matsuzawa, Y.; Sumida, H.; Matsui, K.; Jinnouchi, H.; Ogawa, H. Significance of a multiple biomarkers strategy including endothelial dysfunction to improve risk stratification for cardiovascular events in patients at high risk for coronary heart disease. J. Am. Coll. Cardiol. 2009, 54, 601-608. [CrossRef] [PubMed]

142. Blann, A.D. A reliable marker of vascular function: Does it exist? Trends Cardiovasc. Med. 2015, 25, 588-591. [CrossRef]

143. Werner, N.; Wassmann, S.; Ahlers, P.; Kosiol, S.; Nickenig, G. Circulating CD31+/annexin V+ apoptotic microparticles correlate with coronary endothelial function in patients with coronary artery disease. Arterioscler. Thromb. Vasc. Biol. 2006, 26, 112-116. [CrossRef]

144. Wang, Y.; Liu, J.; Chen, X.; Sun, H.; Peng, S.; Kuang, Y.; Pi, J.; Zhuang, T.; Zhang, L.; Yu, Z.; et al. Dysfunctional endothelial-derived microparticles promote inflammatory macrophage formation via NF-small ka, CyrillicB and IL-1beta signal pathways. J. Cell. Mol. Med. 2019, 23, 476-486. [CrossRef]

145. Radecke, C.E.; Warrick, A.E.; Singh, G.D.; Rogers, J.H.; Simon, S.I.; Armstrong, E.J. Coronary artery endothelial cells and microparticles increase expression of VCAM-1 in myocardial infarction. Thromb. Haemost. 2015, 113, 605-616. [CrossRef]

146. Gkaliagkousi, E.; Gavriilaki, E.; Vasileiadis, I.; Nikolaidou, B.; Yiannaki, E.; Lazaridis, A.; Triantafyllou, A.; Anyfanti, P.; Markala, D.; Zarifis, I.; et al. Endothelial Microvesicles Circulating in Peripheral and Coronary Circulation Are Associated with Central Blood Pressure in Coronary Artery Disease. Am. J. Hypertens. 2019, 32, 1199-1205. [CrossRef]

147. Yamamoto, E.; Sugiyama, S.; Hirata, Y.; Tokitsu, T.; Tabata, N.; Fujisue, K.; Sugamura, K.; Sakamoto, K.; Tsujita, K.; Matsumura, T.; et al. Prognostic significance of circulating leukocyte subtype counts in patients with coronary artery disease. Atherosclerosis 2016, 255, 210-216. [CrossRef] 
148. Urbanski, K.; Ludew, D.; Filip, G.; Filip, M.; Sagan, A.; Szczepaniak, P.; Grudzien, G.; Sadowski, J.; Jasiewicz-Honkisz, B.; Sliwa, T.; et al. CD14(+)CD16(++) "nonclassical" monocytes are associated with endothelial dysfunction in patients with coronary artery disease. Thromb. Haemost. 2017, 117, 971-980. [CrossRef]

149. Arnold, K.A.; Blair, J.E.; Paul, J.D.; Shah, A.P.; Nathan, S.; Alenghat, F.J. Monocyte and macrophage subtypes as paired cell biomarkers for coronary artery disease. Exp. Physiol. 2019, 104, 1343-1352. [CrossRef]

150. Leone, A.; Moncada, S.; Vallance, P.; Calver, A.; Collier, J. Accumulation of an endogenous inhibitor of nitric oxide synthesis in chronic renal failure. Lancet 1992, 339, 572-575. [CrossRef]

151. Dimitroulas, T.; Sandoo, A.; Kitas, G.D. Asymmetric dimethylarginine as a surrogate marker of endothelial dysfunction and cardiovascular risk in patients with systemic rheumatic diseases. Int. J. Mol. Sci. 2012, 13, 12315-12335. [CrossRef] [PubMed]

152. Dimitroulas, T.; Giannakoulas, G.; Papadopoulou, K.; Sfetsios, T.; Karvounis, H.; Dimitroula, H.; Parcharidou, D.; Koliakos, G.; Garyfallos, A.; Styliadis, I.; et al. Left atrial volume and N-terminal pro-B type natriuretic peptide are associated with elevated pulmonary artery pressure in patients with systemic sclerosis. Clin. Rheumatol. 2010, 29, 957-964. [CrossRef]

153. Dimitroulas, T.; Hodson, J.; Sandoo, A.; Smith, J.; Kitas, G.D. Endothelial injury in rheumatoid arthritis: A crosstalk between dimethylarginines and systemic inflammation. Arthritis Res. Ther. 2017, 19, 32. [CrossRef]

154. Surdacki, A.; Nowicki, M.; Sandmann, J.; Tsikas, D.; Boeger, R.H.; Bode-Boeger, S.M.; Kruszelnicka-Kwiatkowska, O.; Kokot, F.; Dubiel, J.S.; Froelich, J.C. Reduced urinary excretion of nitric oxide metabolites and increased plasma levels of asymmetric dimethylarginine in men with essential hypertension. J. Cardiovasc. Pharmacol. 1999, 33, 652-658. [CrossRef]

155. Eid, H.M.; Arnesen, H.; Hjerkinn, E.M.; Lyberg, T.; Seljeflot, I. Relationship between obesity, smoking, and the endogenous nitric oxide synthase inhibitor, asymmetric dimethylarginine. Metabolism 2004, 53, 1574-1579. [CrossRef]

156. Lundman, P.; Eriksson, M.J.; Stühlinger, M.; Cooke, J.P.; Hamsten, A.; Tornvall, P. Mild-to-moderate hypertriglyceridemia in young men is associated with endothelial dysfunction and increased plasma concentrations of asymmetric dimethylarginine. $J$. Am. Coll. Cardiol. 2001, 38, 111-116. [CrossRef]

157. Altinova, A.E.; Arslan, M.; Sepici-Dincel, A.; Akturk, M.; Altan, N.; Toruner, F.B. Uncomplicated type 1 diabetes is associated with increased asymmetric dimethylarginine concentrations. J. Clin. Endocrinol. Metab. 2007, 92, 1881-1885. [CrossRef] [PubMed]

158. Abbasi, F.; Asagmi, T.; Cooke, J.P.; Lamendola, C.; McLaughlin, T.; Reaven, G.M.; Stuehlinger, M.; Tsao, P.S. Plasma concentrations of asymmetric dimethylarginine are increased in patients with type 2 diabetes mellitus. Am. J. Cardiol. 2001, 88, 1201-1203. [CrossRef]

159. Leong, T.; Zylberstein, D.; Graham, I.; Lissner, L.; Ward, D.; Fogarty, J.; Bengtsson, C.; Bjorkelund, C.; Thelle, D.; Swedish-IrishNorwegian, C. Asymmetric dimethylarginine independently predicts fatal and nonfatal myocardial infarction and stroke in women: 24-year follow-up of the population study of women in Gothenburg. Arterioscler. Thromb. Vasc. Biol. 2008, 28, 961-967. [CrossRef]

160. Yoo, J.H.; Lee, S.C. Elevated levels of plasma homocyst(e)ine and asymmetric dimethylarginine in elderly patients with stroke. Atherosclerosis 2001, 158, 425-430. [CrossRef]

161. Dowsett, L.; Higgins, E.; Alanazi, S.; Alshuwayer, N.A.; Leiper, F.C.; Leiper, J. ADMA: A Key Player in the Relationship between Vascular Dysfunction and Inflammation in Atherosclerosis. J. Clin. Med. 2020, 9, 3026. [CrossRef]

162. Mangiacapra, F.; Conte, M.; Demartini, C.; Muller, O.; Delrue, L.; Dierickx, K.; Di Sciascio, G.; Trimarco, B.; De Bruyne, B.; Wijns, W.; et al. Relationship of asymmetric dimethylarginine (ADMA) with extent and functional severity of coronary atherosclerosis. Int. J. Cardiol. 2016, 220, 629-633. [CrossRef]

163. Jarzebska, N.; Mangoni, A.A.; Martens-Lobenhoffer, J.; Bode-Boger, S.M.; Rodionov, R.N. The Second Life of Methylarginines as Cardiovascular Targets. Int. J. Mol. Sci. 2019, 20, 4592. [CrossRef] [PubMed]

164. Kielstein, J.T.; Martens-Lobenhoffer, J.; Vollmer, S.; Bode-Boger, S.M. L-Arginine, ADMA, SDMA, creatinine, MDRD formula: Detour to renal function testing. J. Nephrol. 2008, 21, 959-961.

165. Schulze, F.; Carter, A.M.; Schwedhelm, E.; Ajjan, R.; Maas, R.; von Holten, R.A.; Atzler, D.; Grant, P.J.; Boger, R.H. Symmetric dimethylarginine predicts all-cause mortality following ischemic stroke. Atherosclerosis 2010, 208, 518-523. [CrossRef]

166. Speer, T.; Rohrer, L.; Blyszczuk, P.; Shroff, R.; Kuschnerus, K.; Krankel, N.; Kania, G.; Zewinger, S.; Akhmedov, A.; Shi, Y.; et al. Abnormal high-density lipoprotein induces endothelial dysfunction via activation of Toll-like receptor-2. Immunity 2013, 38, 754-768. [CrossRef] [PubMed]

167. Jud, P.; Hafner, F.; Verheyen, N.; Meinitzer, A.; Gary, T.; Brodmann, M.; Seinost, G.; Hackl, G. Homoarginine/ADMA ratio and homoarginine/SDMA ratio as independent predictors of cardiovascular mortality and cardiovascular events in lower extremity arterial disease. Sci. Rep. 2018, 8, 14197. [CrossRef] [PubMed]

168. Aguilera, E.; Serra-Planas, E.; Granada, M.L.; Pellitero, S.; Reverter, J.L.; Alonso, N.; Soldevila, B.; Mauricio, D.; Puig-Domingo, M. Relationship of YKL-40 and adiponectin and subclinical atherosclerosis in asymptomatic patients with type 1 diabetes mellitus from a European Mediterranean population. Cardiovasc. Diabetol. 2015, 14, 121. [CrossRef]

169. Fadaei, R.; Shateri, H.; DiStefano, J.K.; Moradi, N.; Mohammadi, M.; Emami, F.; Aghajani, H.; Ziamajidi, N. Higher circulating levels of ANGPTL8 are associated with body mass index, triglycerides, and endothelial dysfunction in patients with coronary artery disease. Mol. Cell Biochem. 2020, 469, 29-39. [CrossRef]

170. Moradi, N.; Fadaei, R.; Emamgholipour, S.; Kazemian, E.; Panahi, G.; Vahedi, S.; Saed, L.; Fallah, S. Association of circulating CTRP9 with soluble adhesion molecules and inflammatory markers in patients with type 2 diabetes mellitus and coronary artery disease. PLoS ONE 2018, 13, e0192159. [CrossRef] [PubMed] 
171. Deng, J.; Qian, X.; Li, J.; Li, Y.; Li, Y.; Luo, Y. Evaluation of serum cysteine-rich protein 61 levels in patients with coronary artery disease. Biomark. Med. 2018, 12, 329-339. [CrossRef]

172. Turan, T.; Akyuz, A.R.; Aykan, A.C.; Kul, S.; Cirakoglu, O.F.; Aslan, A.O.; Gul, I.; Ucar, U.; Demir, S.; Celik, S. Plasma Endocan Levels in Patients with Isolated Coronary Artery Ectasia. Angiology 2016, 67, 932-936. [CrossRef]

173. Efe, S.C.; Demirci, K.; Ozturk, S.; Gurbuz, A.S.; Poci, N.; Kilicgedik, A.; Guler, A.; Yilmaz, M.F.; Izgi, I.A.; Kirma, C. Serum endocan levels in patients with cardiac syndrome X. Herz 2018, 43, 359-363. [CrossRef]

174. Aksan, G.; Gedikli, O.; Keskin, K.; Nar, G.; Inci, S.; Yildiz, S.S.; Kaplan, O.; Soylu, K.; Kilickesmez, K.O.; Sahin, M. Is galectin-3 a biomarker, a player-or both-in the presence of coronary atherosclerosis? J. Investig. Med. 2016, 64, 764-770. [CrossRef]

175. Maneerat, Y.; Prasongsukarn, K.; Benjathummarak, S.; Dechkhajorn, W.; Chaisri, U. Increased alpha-defensin expression is associated with risk of coronary heart disease: A feasible predictive inflammatory biomarker of coronary heart disease in hyperlipidemia patients. Lipids Health Dis. 2016, 15, 117. [CrossRef] [PubMed]

176. Yin, C.; Hu, W.; Wang, M.; Lv, W.; Jia, T.; Xiao, Y. Irisin as a mediator between obesity and vascular inflammation in Chinese children and adolescents. Nutr. Metab. Cardiovasc. Dis. 2020, 30, 320-329. [CrossRef]

177. Huerta-Delgado, A.S.; Roffe-Vazquez, D.N.; Gonzalez-Gil, A.M.; Villarreal-Calderon, J.R.; Tamez-Rivera, O.; RodriguezGutierrez, N.A.; Castillo, E.C.; Silva-Platas, C.; Garcia-Rivas, G.; Elizondo-Montemayor, L. Serum Irisin Levels, Endothelial Dysfunction, and Inflammation in Pediatric Patients with Type 2 Diabetes Mellitus and Metabolic Syndrome. J. Diabetes Res. 2020, 2020, 1949415. [CrossRef]

178. Guo, W.; Zhang, B.; Wang, X. Lower irisin levels in coronary artery disease: A meta-analysis. Minerva Endocrinol. 2020, 45, 61-69. [CrossRef]

179. Sairam, S.G.; Sola, S.; Barooah, A.; Javvaji, S.K.; Jaipuria, J.; Venkateshan, V.; Chelli, J.; Sanjeevi, C.B. The role of Lp-PLA2 and biochemistry parameters as potential biomarkers of coronary artery disease in Asian South-Indians: A case-control study. Cardiovasc. Diagn. Ther. 2017, 589-597. [CrossRef]

180. Naka, K.K.; Papathanassiou, K.; Bechlioulis, A.; Pappas, K.; Tigas, S.; Makriyiannis, D.; Antoniou, S.; Kazakos, N.; Margeli, A.; Papassotiriou, I.; et al. Association of vascular indices with novel circulating biomarkers as prognostic factors for cardiovascular complications in patients with type 2 diabetes mellitus. Clin. Biochem. 2018, 53, 31-37. [CrossRef] [PubMed]

181. Grzywocz, P.; Mizia-Stec, K.; Wybraniec, M.; Chudek, J. Adipokines and endothelial dysfunction in acute myocardial infarction and the risk of recurrent cardiovascular events. J. Cardiovasc. Med. 2015, 16, 37-44.

182. Ashraf, H.; Soltani, D.; Sobh-Rakhshankhah, A.; Jafari, S.; Boroumand, M.A.; Goudarzi, V.; Vasheghani Farahani, A.; Masoudkabir, F. Visfatin as marker of isolated coronary artery ectasia and its severity. Cytokine 2019, 113, 216-220. [CrossRef]

183. Safdar, B.; Guo, X.; Johnson, C.; D’Onofrio, G.; Dziura, J.; Sinusas, A.J.; Testani, J.; Rao, V.; Desir, G. Elevated renalase levels in patients with acute coronary microvascular dysfunction-A possible biomarker for ischemia. Int. J. Cardiol. 2019, 279, 155-161. [CrossRef]

184. Han, W.; Wei, Z.; Zhang, H.; Geng, C.; Dang, R.; Yang, M.; Zhang, J.; Wang, C.; Jiang, P. The Association Between Sortilin and Inflammation in Patients with Coronary Heart Disease. J. Inflamm. Res. 2020, 13, 71-79. [CrossRef]

185. Mekonnen, G.; Corban, M.T.; Hung, O.Y.; Eshtehardi, P.; Eapen, D.J.; Al-Kassem, H.; Rasoul-Arzrumly, E.; Gogas, B.D.; McDaniel, M.C.; Pielak, T.; et al. Plasma soluble urokinase-type plasminogen activator receptor level is independently associated with coronary microvascular function in patients with non-obstructive coronary artery disease. Atherosclerosis 2015, $239,55-60$. [CrossRef]

186. Leucker, T.M.; Weiss, R.G.; Schar, M.; Bonanno, G.; Mathews, L.; Jones, S.R.; Brown, T.T.; Moore, R.; Afework, Y.; Gerstenblith, G.; et al. Coronary Endothelial Dysfunction Is Associated with Elevated Serum PCSK9 Levels in People With HIV Independent of Low-Density Lipoprotein Cholesterol. J. Am. Heart Assoc. 2018, 7, e009996. [CrossRef] [PubMed]

187. Caselli, C.; Del Turco, S.; Ragusa, R.; Lorenzoni, V.; De Graaf, M.; Basta, G.; Scholte, A.; De Caterina, R.; Neglia, D. Association of PCSK9 plasma levels with metabolic patterns and coronary atherosclerosis in patients with stable angina. Cardiovasc. Diabetol. 2019, 18, 144. [CrossRef] [PubMed]

188. Paapstel, K.; Kals, J.; Eha, J.; Tootsi, K.; Ottas, A.; Piir, A.; Jakobson, M.; Lieberg, J.; Zilmer, M. Inverse relations of serum phosphatidylcholines and lysophosphatidylcholines with vascular damage and heart rate in patients with atherosclerosis. Nutr. Metab. Cardiovasc. Dis. 2018, 28, 44-52. [CrossRef]

189. Zhang, Y.; Zhang, L.; Wang, Y.; Ding, H.; Xue, S.; Yu, H.; Hu, L.; Qi, H.; Wang, Y.; Zhu, W.; et al. KCNQ1OT1, HIF1A-AS2 and APOA1-AS are promising novel biomarkers for diagnosis of coronary artery disease. Clin. Exp. Pharmacol. Physiol. 2019, 46, 635-642. [CrossRef]

190. Xu, Y.; Shao, B. Circulating lncRNA IFNG-AS1 expression correlates with increased disease risk, higher disease severity and elevated inflammation in patients with coronary artery disease. J. Clin. Lab. Anal. 2018, 32, e22452. [CrossRef] [PubMed]

191. Bai, R.; Yang, Q.; Xi, R.; Li, L.; Shi, D.; Chen, K. miR-941 as a promising biomarker for acute coronary syndrome. BMC Cardiovasc. Disord. 2017, 17, 227. [CrossRef] [PubMed]

192. Reddy, L.L.; Shah, S.A.V.; Ponde, C.K.; Rajani, R.M.; Ashavaid, T.F. Circulating miRNA-33: A potential biomarker in patients with coronary artery disease. Biomarkers 2019, 24, 36-42. [CrossRef]

193. Wang, W.; Li, Z.; Zheng, Y.; Yan, M.; Cui, Y.; Jiang, J. Circulating microRNA-92a level predicts acute coronary syndrome in diabetic patients with coronary heart disease. Lipids Health Dis. 2019, 18, 22. [CrossRef] [PubMed] 
194. Horvath, M.; Horvathova, V.; Hajek, P.; Stechovsky, C.; Honek, J.; Senolt, L.; Veselka, J. MicroRNA-331 and microRNA-151-3p as biomarkers in patients with ST-segment elevation myocardial infarction. Sci. Rep. 2020, 10, 5845. [CrossRef]

195. Ling, H.; Guo, Z.; Shi, Y.; Zhang, L.; Song, C. Serum Exosomal MicroRNA-21, MicroRNA-126, and PTEN Are Novel Biomarkers for Diagnosis of Acute Coronary Syndrome. Front. Physiol. 2020, 11, 654. [CrossRef] [PubMed]

196. Wu, S.; Sun, H.; Sun, B. MicroRNA-145 is involved in endothelial cell dysfunction and acts as a promising biomarker of acute coronary syndrome. Eur. J. Med. Res. 2020, 25, 2. [CrossRef]

197. Chen, T.; Wang, Z.Y.; Li, C.C. miRNA-22 as a Candidate Diagnostic Biomarker for Coronary Slow Flow. Cardiol. Res. Pract. 2020, 2020, 7490942. [CrossRef]

198. Danaii, S.; Shiri, S.; Dolati, S.; Ahmadi, M.; Ghahremani-Nasab, L.; Amiri, A.; Kamrani, A.; Samadi Kafil, H.; Chakari-Khiavi, F.; Hojjat-Farsangi, M.; et al. The Association between Inflammatory Cytokines and miRNAs with Slow Coronary Flow Phenomenon. Iran. J. Allergy Asthma Immunol. 2020, 19, 56-64. [CrossRef]

199. Vita, J.A. Endothelial function. Circulation 2011, 124, e906-e912. [CrossRef]

200. Cooper, S.; Teoh, H.; Campeau, M.A.; Verma, S.; Leask, R.L. Empagliflozin restores the integrity of the endothelial glycocalyx in vitro. Mol. Cell Biochem. 2019, 459, 121-130. [CrossRef]

201. Aini, K.; Fukuda, D.; Tanaka, K.; Higashikuni, Y.; Hirata, Y.; Yagi, S.; Kusunose, K.; Yamada, H.; Soeki, T.; Sata, M. Vildagliptin, a DPP-4 Inhibitor, Attenuates Endothelial Dysfunction and Atherogenesis in Nondiabetic Apolipoprotein E-Deficient Mice. Int. Heart J. 2019, 60, 1421-1429. [CrossRef]

202. Sardu, C.; Paolisso, P.; Sacra, C.; Mauro, C.; Minicucci, F.; Portoghese, M.; Rizzo, M.R.; Barbieri, M.; Sasso, F.C.; D’Onofrio, N.; et al. Effects of Metformin Therapy on Coronary Endothelial Dysfunction in Patients with Prediabetes with Stable Angina and Nonobstructive Coronary Artery Stenosis: The CODYCE Multicenter Prospective Study. Diabetes Care 2019, 42, $1946-1955$. [CrossRef]

203. He, Z.; Du, X.; Wu, Y.; Hua, L.; Wan, L.; Yan, N. Simvastatin promotes endothelial dysfunction by activating the Wnt/betacatenin pathway under oxidative stress. Int. J. Mol. Med. 2019, 44, 1289-1298. [PubMed]

204. Li, X.; Xiao, H.; Lin, C.; Sun, W.; Wu, T.; Wang, J.; Chen, B.; Chen, X.; Cheng, D. Synergistic effects of liposomes encapsulating atorvastatin calcium and curcumin and targeting dysfunctional endothelial cells in reducing atherosclerosis. Int. J. Nanomed. 2019, 14, 649-665. [CrossRef]

205. Bacchiega, B.C.; Bacchiega, A.B.; Usnayo, M.J.; Bedirian, R.; Singh, G.; Pinheiro, G.D. Interleukin 6 Inhibition and Coronary Artery Disease in a High-Risk Population: A Prospective Community-Based Clinical Study. J. Am. Heart Assoc. 2017, 6, e005038. [CrossRef]

206. Ikonomidis, I.; Pavlidis, G.; Katsimbri, P.; Lambadiari, V.; Parissis, J.; Andreadou, I.; Tsoumani, M.; Boumpas, D.; Kouretas, D.; Iliodromitis, E. Tocilizumab improves oxidative stress and endothelial glycocalyx: A mechanism that may explain the effects of biological treatment on COVID-19. Food Chem. Toxicol. 2020, 145, 111694. [CrossRef] [PubMed]

207. Yang, X.; Wan, M.; Cheng, Z.; Wang, Z.; Wu, Q. Tofacitinib inhibits ox-LDL-induced adhesion of THP-1 monocytes to endothelial cells. Artif. Cells Nanomed. Biotechnol. 2019, 47, 2775-2782. [CrossRef]

208. Ashry, N.A.; Abdelaziz, R.R.; Suddek, G.M. The potential effect of imatinib against hypercholesterolemia induced atherosclerosis, endothelial dysfunction and hepatic injury in rabbits. Life Sci. 2020, 243, 117275. [CrossRef]

209. Zhou, X.; Cai, J.; Liu, W.; Wu, X.; Gao, C. Cysteinyl leukotriene receptor type 1 (CysLT1R) antagonist zafirlukast protects against TNF-alpha-induced endothelial inflammation. Biomed. Pharmacother. 2019, 111, 452-459. [CrossRef]

210. Pang, J.; Hu, P.; Wang, J.; Jiang, J.; Lai, J. Vorapaxar stabilizes permeability of the endothelial barrier under cholesterol stimulation via the AKT/JNK and NFkappaB signaling pathways. Mol. Med. Rep. 2019, 19, 5291-5300. [PubMed]

211. Campo, G.; Vieceli Dalla Sega, F.; Pavasini, R.; Aquila, G.; Gallo, F.; Fortini, F.; Tonet, E.; Cimaglia, P.; Del Franco, A.; Pestelli, G.; et al. Biological effects of ticagrelor over clopidogrel in patients with stable coronary artery disease and chronic obstructive pulmonary disease. Thromb. Haemost. 2017, 117, 1208-1216. [CrossRef]

212. Vieceli Dalla Sega, F.; Fortini, F.; Aquila, G.; Pavasini, R.; Biscaglia, S.; Bernucci, D.; Del Franco, A.; Tonet, E.; Rizzo, P.; Ferrari, R.; et al. Ticagrelor Improves Endothelial Function by Decreasing Circulating Epidermal Growth Factor (EGF). Front. Physiol. 2018, 9, 337. [CrossRef]

213. Aquila, G.; Vieceli Dalla Sega, F.; Marracino, L.; Pavasini, R.; Cardelli, L.S.; Piredda, A.; Scoccia, A.; Martino, V.; Fortini, F.; Bononi, I.; et al. Ticagrelor Increases SIRT1 and HES1 mRNA Levels in Peripheral Blood Cells from Patients with Stable Coronary Artery Disease and Chronic Obstructive Pulmonary Disease. Int. J. Mol. Sci. 2020, 21, 1576. [CrossRef] [PubMed]

214. Flanagan, T.W.; Sebastian, M.N.; Battaglia, D.M.; Foster, T.P.; Maillet, E.L.; Nichols, C.D. Activation of 5-HT 2 receptors reduces inflammation in vascular tissue and cholesterol levels in high-fat diet-fed apolipoprotein E knockout mice. Sci. Rep. 2019, 9, 1-10. [CrossRef] [PubMed]

215. Xin, R.; An, D.; Li, Y.; Fu, J.; Huang, F.; Zhu, Q. Fenofibrate improves vascular endothelial function in diabetic mice. Biomed. Pharmacother. 2019, 112, 108722. [CrossRef]

216. Kubo, M.; Kiyohara, Y.; Kato, I.; Tanizaki, Y.; Arima, H.; Tanaka, K.; Nakamura, H.; Okubo, K.; Iida, M. Trends in the incidence, mortality, and survival rate of cardiovascular disease in a Japanese community: The Hisayama study. Stroke 2003, 34, $2349-2354$. [CrossRef] 
217. Adams, V.; Reich, B.; Uhlemann, M.; Niebauer, J. Molecular effects of exercise training in patients with cardiovascular disease: Focus on skeletal muscle, endothelium, and myocardium. Am. J. Physiol. Heart Circ. Physiol. 2017, 313, H72-H88. [CrossRef] [PubMed]

218. Fletcher, G.F.; Ades, P.A.; Kligfield, P.; Arena, R.; Balady, G.J.; Bittner, V.A.; Coke, L.A.; Fleg, J.L.; Forman, D.E.; Gerber, T.C.; et al. Prevention, Exercise standards for testing and training: A scientific statement from the American Heart Association. Circulation 2013, 128, 873-934. [CrossRef] [PubMed]

219. Aoyama, A.; Yamaoka-Tojo, M.; Obara, S.; Shimizu, E.; Fujiyoshi, K.; Noda, C.; Matsunaga, A.; Ako, J. Acute Effects of Whole-Body Vibration Training on Endothelial Function and Cardiovascular Response in Elderly Patients with Cardiovascular Disease A Single-Arm Pilot Study. Int. Heart J. 2019, 60, 854-861. [CrossRef]

220. Gardner, A.W.; Parker, D.E.; Montgomery, P.S. Changes in vascular and inflammatory biomarkers after exercise rehabilitation in patients with symptomatic peripheral artery disease. J. Vasc. Surg. 2019, 70, 1280-1290. [CrossRef]

221. Pedralli, M.L.; Marschner, R.A.; Kollet, D.P.; Neto, S.G.; Eibel, B.; Tanaka, H.; Lehnen, A.M. Different exercise training modalities produce similar endothelial function improvements in individuals with prehypertension or hypertension: A randomized clinical trial. Sci. Rep. 2020, 10, 1-9. [CrossRef] [PubMed]

222. Seals, D.R.; Nagy, E.E.; Moreau, K.L. Aerobic exercise training and vascular function with ageing in healthy men and women. J. Physiol. 2019, 597, 4901-4914. [CrossRef] [PubMed]

223. Witkowski, S.; Serviente, C. Endothelial dysfunction and menopause: Is exercise an effective countermeasure? Climacteric 2018, 21, 267-275. [CrossRef]

224. Sacks, F.M.; Lichtenstein, A.H.; Wu, J.H.Y.; Appel, L.J.; Creager, M.A.; Kris-Etherton, P.M.; Miller, M.; Rimm, E.B.; Rudel, L.L.; Robinson, J.G.; et al. Dietary Fats and Cardiovascular Disease: A Presidential Advisory from the American Heart Association. Circulation 2017, 136, e1-e23. [CrossRef] [PubMed]

225. Stone, N.J.; Robinson, J.G.; Lichtenstein, A.H.; Bairey Merz, C.N.; Blum, C.B.; Eckel, R.H.; Goldberg, A.C.; Gordon, D.; Levy, D.; Lloyd-Jones, D.M. 2013 ACC/AHA guideline on the treatment of blood cholesterol to reduce atherosclerotic cardiovascular risk in adults: A report of the American College of Cardiology/American Heart Association Task Force on Practice Guidelines. J. Am. Coll. Cardiol. 2014, 63, 2889-2934. [CrossRef]

226. DeSalvo, K.B.; Olson, R.; Casavale, K.O. Dietary guidelines for Americans. JAMA 2016, 315, 457-458. [CrossRef] [PubMed]

227. Davis, C.R.; Hodgson, J.M.; Woodman, R.; Bryan, J.; Wilson, C.; Murphy, K.J. A Mediterranean diet lowers blood pressure and improves endothelial function: Results from the MedLey randomized intervention trial. Am. J. Clin. Nutr. 2017, 105, 1305-1313. [CrossRef] [PubMed]

228. Dinu, M.; Pagliai, G.; Casini, A.; Sofi, F. Mediterranean diet and multiple health outcomes: An umbrella review of meta-analyses of observational studies and randomised trials. Eur J. Clin. Nutr. 2018, 72, 30-43. [CrossRef] [PubMed]

229. Eleftheriou, D.; Benetou, V.; Trichopoulou, A.; La Vecchia, C.; Bamia, C. Mediterranean diet and its components in relation to all-cause mortality: Meta-analysis. Br. J. Nutr. 2018, 120, 1081-1097. [CrossRef]

230. Satija, A.; Bhupathiraju, S.N.; Rimm, E.B.; Spiegelman, D.; Chiuve, S.E.; Borgi, L.; Willett, W.C.; Manson, J.E.; Sun, Q.; Hu, F.B. Plant-Based Dietary Patterns and Incidence of Type 2 Diabetes in US Men and Women: Results from Three Prospective Cohort Studies. PLoS Med. 2016, 13, e1002039. [CrossRef]

231. Schwingshackl, L.; Hoffmann, G. Adherence to Mediterranean diet and risk of cancer: A systematic review and meta-analysis of observational studies. Int. J. Cancer 2014, 135, 1884-1897. [CrossRef]

232. Yubero-Serrano, E.M.; Fernandez-Gandara, C.; Garcia-Rios, A.; Rangel-Zuniga, O.A.; Gutierrez-Mariscal, F.M.; Torres-Pena, J.D.; Marin, C.; Lopez-Moreno, J.; Castano, J.P.; Delgado-Lista, J.; et al. Mediterranean diet and endothelial function in patients with coronary heart disease: An analysis of the CORDIOPREV randomized controlled trial. PLoS Med. 2020, 17, e1003282. [CrossRef]

233. Schwingshackl, L.; Morze, J.; Hoffmann, G. Mediterranean diet and health status: Active ingredients and pharmacological mechanisms. Br. J. Pharmacol. 2020, 177, 1241-1257. [CrossRef] [PubMed]

234. Delgado, A.M.; Almeida, M.D.V.; Parisi, S. Chemistry of the Mediterranean Diet; Springer: Berlin/Heidelberg, Germany, 2017.

235. WHO. WHO Global Report on Trends in Prevalence of Tobacco Use 2000-2025; WHO: Geneva, Switzerland, 2019.

236. Golbidi, S.; Edvinsson, L.; Laher, I. Smoking and Endothelial Dysfunction. Curr. Vasc. Pharmacol. 2020, 18, 1-11. [CrossRef] [PubMed]

237. Hackshaw, A.; Morris, J.K.; Boniface, S.; Tang, J.L.; Milenkovic, D. Low cigarette consumption and risk of coronary heart disease and stroke: Meta-analysis of 141 cohort studies in 55 study reports. BMJ 2018, 360, j5855. [CrossRef] [PubMed]

238. Carnevale, R.; Sciarretta, S.; Violi, F.; Nocella, C.; Loffredo, L.; Perri, L.; Peruzzi, M.; Marullo, A.G.; De Falco, E.; Chimenti, I.; et al. Acute Impact of Tobacco vs Electronic Cigarette Smoking on Oxidative Stress and Vascular Function. Chest 2016, 150, 606-612. [CrossRef]

239. Skotsimara, G.; Antonopoulos, A.S.; Oikonomou, E.; Siasos, G.; Ioakeimidis, N.; Tsalamandris, S.; Charalambous, G.; Galiatsatos, N.; Vlachopoulos, C.; Tousoulis, D. Cardiovascular effects of electronic cigarettes: A systematic review and meta-analysis. Eur. J. Prev. Cardiol. 2019, 26, 1219-1228. [CrossRef]

240. Xue, C.; Chen, Q.Z.; Bian, L.; Yin, Z.F.; Xu, Z.J.; Zhang, A.L.; Xie, Y.S.; Zhang, H.L.; Du, R.; Wang, C.Q. Effects of Smoking Cessation with Nicotine Replacement Therapy on Vascular Endothelial Function, Arterial Stiffness, and Inflammation Response in Healthy Smokers. Angiology 2019, 70, 719-725. [CrossRef]

241. Sies, H. Oxidative stress: A concept in redox biology and medicine. Redox Biol. 2015, 4, 180-183. [CrossRef] 
242. Daiber, A.; Steven, S.; Weber, A.; Shuvaev, V.V.; Muzykantov, V.R.; Laher, I.; Li, H.; Lamas, S.; Munzel, T. Targeting vascular (endothelial) dysfunction. Br. J. Pharmacol. 2017, 174, 1591-1619. [CrossRef] [PubMed]

243. Schulz, M.; Iwersen-Bergmann, S.; Andresen, H.; Schmoldt, A. Therapeutic and toxic blood concentrations of nearly 1,000 drugs and other xenobiotics. Crit. Care 2012, 16, 1-4. [CrossRef]

244. Steven, S.; Frenis, K.; Oelze, M.; Kalinovic, S.; Kuntic, M.; Bayo Jimenez, M.T.; Vujacic-Mirski, K.; Helmstadter, J.; Kroller-Schon, S.; Munzel, T.; et al. Vascular Inflammation and Oxidative Stress: Major Triggers for Cardiovascular Disease. Oxid. Med. Cell Longev. 2019, 2019, 7092151. [CrossRef]

245. Aschauer, S.; Gouya, G.; Klickovic, U.; Storka, A.; Weisshaar, S.; Vollbracht, C.; Krick, B.; Weiss, G.; Wolzt, M. Effect of systemic high dose vitamin $\mathrm{C}$ therapy on forearm blood flow reactivity during endotoxemia in healthy human subjects. Vascul. Pharmacol. 2014, 61, 25-29. [CrossRef]

246. Hashim Fauzy, F.; Mohd Zainudin, M.; Ismawi, H.R.; Elshami, T.F.T. Piper sarmentosum Leaves Aqueous Extract Attenuates Vascular Endothelial Dysfunction in Spontaneously Hypertensive Rats. Evid. Based Complement. Altern. Med. 2019, $2019,7198592$. [CrossRef]

247. Akinyemi, A.J.; Oboh, G.; Ademiluyi, A.O.; Boligon, A.A.; Athayde, M.L. Effect of Two Ginger Varieties on Arginase Activity in Hypercholesterolemic Rats. J. Acupunct. Meridian Stud. 2016, 9, 80-87. [CrossRef]

248. Yi, B.; Nguyen, M.C.; Won, M.H.; Kim, Y.M.; Ryoo, S. Arginase Inhibitor 2,3,5,4'-Tetrahydroxystilbene-2-O-beta-D-Glucoside Activates Endothelial Nitric Oxide Synthase and Improves Vascular Function. Planta Med. 2017, 83, 210-216. [PubMed]

249. Usharani, P.; Merugu, P.L.; Nutalapati, C. Evaluation of the effects of a standardized aqueous extract of Phyllanthus emblica fruits on endothelial dysfunction, oxidative stress, systemic inflammation and lipid profile in subjects with metabolic syndrome: A randomised, double blind, placebo controlled clinical study. BMC Complement. Altern. Med. 2019, $19,97$.

250. Usharani, P.; Fatima, N.; Kumar, C.U.; Kishan, P. Evaluation of a highly standardized Withania somnifera extract on endothelial dysfunction and biomarkers of oxidative stress in patients with type 2 diabetes mellitus: A randomized, double blind, placebo controlled study. Int. J. Ayurveda Pharma Res. 2014, 2, 22-32.

251. Pingali Usharani, N.F.; Muralidhar, N. Effects of Phyllanthus emblica extract on endothelial dysfunction and biomarkers of oxidative stress in patients with type 2 diabetes mellitus: A randomized, double-blind, controlled study. Diabetes Metab. Syndr. Obes. 2013, 6, 275.

252. Dower, J.I.; Geleijnse, J.M.; Gijsbers, L.; Schalkwijk, C.; Kromhout, D.; Hollman, P.C. Supplementation of the pure flavonoids epicatechin and quercetin affects some biomarkers of endothelial dysfunction and inflammation in (pre) hypertensive adults: A randomized double-blind, placebo-controlled, crossover trial. J. Nutr. 2015, 145, 1459-1463. [CrossRef] [PubMed]

253. Marques, B.; Trindade, M.; Aquino, J.; Cunha, A.; Gismondi, R.; Neves, M.; Oigman, W. Beneficial effects of acute trans-resveratrol supplementation in treated hypertensive patients with endothelial dysfunction. Clin. Exp. Hypertens. 2018, 40, 218-223. [CrossRef] [PubMed] 